\title{
MITOCHONDRIA (AND OTHER CYTOPLASMIC STRUCTURES) IN TISSUE CULTURES
}

\author{
MARGARET REED LEWIS AND WARREN HARMON LEWIS ${ }^{1}$ \\ From the Anatomical Laboratory, Johns Hopkins Medical School, and the Marine \\ Biological Laboratory, Woods Hole, Mass.
}

TWENTY-SIX FIGURES

CONTENTS

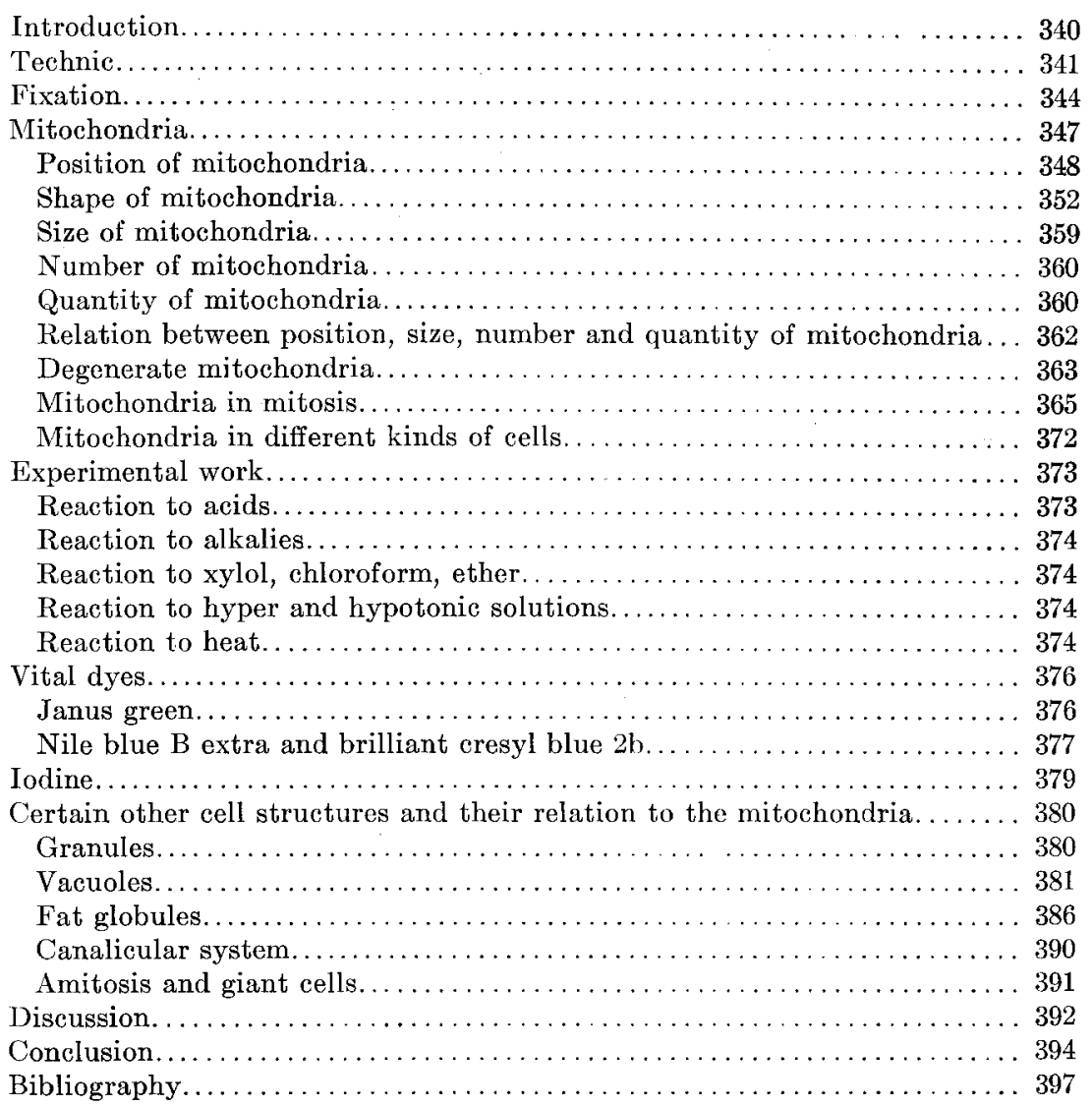

1 We are indebted to the Marine Biological Laboratory for the use of a room during the summer of 1914 . 


\section{INTRODUCTION}

Tissue cultures afford a new and somewhat different method from that usually employed for the study of many cell structures. It enables one to compare the living with the fixed material. In fact, one can study the same cell while living, during the process of fixation, and later as a stained permanent preparation. It also enables one to follow the changes which take place in the living cell from minute to minute. Above all, tissue cultures afford a method by which we can experiment on the cells and mitochondria. And through such methods only do we believe a correct interpretation of the significance of mitochondria is to be found.

In spite of the new and different environment of the tissue, i.e., its isolation from the rest of the embryo; the substitution of a simple Locke's solution for normal plasma; the contact with the cover-slip; and the absence of a circulation, which continually renews the food-supply and removes the waste, the cells of the tissue cultures are apparently quite normal during the first two or three days and exhibit no noticeable changes except the characteristic configuration of the growth. How greatly the new environment disturbs the normal metabolic processes of the cell is impossible to surmise. The cells are in such a thin layer that each cell is probably as well bathed by the Locke's solution as in the embryo it would have been bathed by plasma or lymph.

In the older cultures the cells lose their normal appearance and show signs of degeneration. Migration, growth and mitosis cease, the cells become smaller and show both cytoplasmic and nuclear changes. This may be due to the fact that the modium lacks both the inorganic and organic substances necessary for the prolonged continuance of life, but when we consider that the same degeneration takes place when tissues are explanted into a plasma medium it seems more probable that the degeneration is due to an excess of waste products accumulated around the cell. 
It is during the first two or three days then that we may compare the cells and their structures with those found in the embryo. The mitochondria have been studied during this early period when their appearance and behavior can be considered normal. The close resemblance of the mitochondria found during this early period to those found in the chick by other observers (Benda, Meves, Duesberg, Dubrueil, Cowdry, etc.) shows that they at least are not noticeably altered in the culture. We are justified, we believe in assuming that our findings concerning mitochondria apply as well to the normal cells within the embryo as they do to the cells of the tissue culture.

\section{TECHNIC}

The ordinary technic for the cultivation of tissues in Locke's solution as described by Lewis and Lewis ('11, '12) was used. We found great variations in the amount, duration and character of growth in different solutions. This was apparently not due to the slight variation that occurs in the weighing out of the salts or sugar, which enter into the composition of the solution, since these can be varied considerably and good growth obtained. The trouble lies either in the distilled water, a contaminated container for the solution, poor chick material, or some manipulation during the process of explantation, which we vary unknowingly. In repeating this work one should make several trials until a solution favorable for growth is obtained. When a favorable solution is once obtained it can be kept for months, provided the dextrose is not added to the stock solution.

Chick embryos were taken out of the egg under aseptic conditions and put into 10 or $20 \mathrm{ec}$ of sterile Locke's solution $(\mathrm{NaCl}$ 0.9 per cent, $\mathrm{CaCl}_{2} 0.025$ per cent, $\mathrm{KCl} 0.042$ per cent, $\mathrm{NaHCO}_{3}$ 0.02 per cent, dextrose 0.25 per cent at $39^{\circ} \mathrm{C}$. A piece a few millimeters in diameter of the desired tissue was then cut out and placed in another dish which contained 10 or $20 \mathrm{cc}$. of sterile Locke's solution at $39^{\circ} \mathrm{C}$. This small piece was then cut up into numerous very small pieces. These were drawn up into 
a fine pipette, usually one at a time, with some of the solution and placed each on a sterile cover-slip which was inverted onto a vaseline (melting point, $46 \pm{ }^{\circ} \mathrm{C}$.) ring on a hollow ground slide. All instruments and cover-slips were sterilized by passing them through the flame, and aseptic precautions were observed throughout.

Great care should be taken to insure absolute cleanliness of the cover-slips. The migrating and dividing cells, as we have already stated, adhere to the cover-slip and utilize it as a means of support, and the presence of grease seems to prevent them from getting a foothold. The small drop should spread out evenly and thinly over the center of the cover-slip so that the surface tension keeps the explanted piece in contact with the cover-slip. The stereotropic cells can thus easily creep out from the piece to the cover-slip on which they migrate towards the periphery of the drop. In cases where the drop is too deep and the small explanted piece falls away from the cover-slip the convex surface of the drop may act as a support for growth.

Growth began within ten to twenty hours and reached a maximum in extent and showed the greatest number of mitotic figures on the second or third day. The cultures were incubated at $39^{\circ} \mathrm{C}$. to $40^{\circ} \mathrm{C}$. in an electric incubator (with a glass in the door). The presence of the electric light which was placed in the same chamber with the cultures for the purpose of maintaining the temperature of the incubator did not seem to affect the growth. Cultures apparently grow as well in the light as in the dark.

Around the piece of explanted tissue the new growth forms a more or less radiating reticulum, a syncytium, or a membranelike sbeet of cells with varying numbers of isolated cells. The growth may be several cells in thickness near the old piece, but toward the periphery there is usually only a single layer of flattened cells which are often scarcely $2 \mu$ in thickness (fig. 1). The entire contents of these peripheral cells can be observed with very little change in focus. The growth is so closely attached to the cover-slip that in many cases the explanted piece can be torn away without injury to the new growth. 


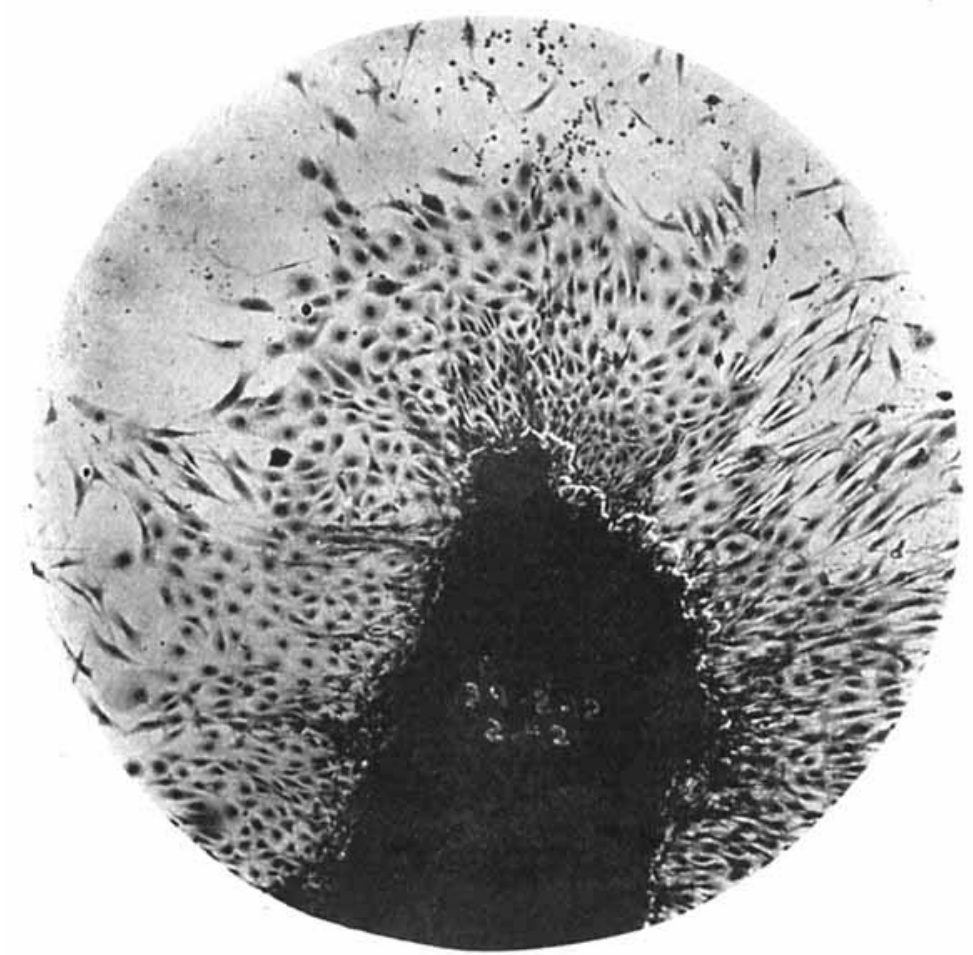

Fig. 1 Photograph of part of a 2-day culture of intestine from an 8-day chick. The black mass is the explanted piece, which is surrounded by the new growth of connective tissue and smooth muscle; there are 13 mitotic figures in this part of the culture; osmic vapor and iron hematoxylin.

Although several different kinds of cells have been identified in the living cultures (Lewis and Lewis) as, for instance, the mesenchyme and connective tissue cells, the heart and smooth muscle syncytium, the endodermal membrane, the yolk membrane, the nerve cell, the kidney tubule cell, etc., nevertheless, the general cytoplasmic structure of the living cell, regardless of the kind of cell, is practically the same except in cases where the cells contain secretory granules. The cytoplasm appears as a homogenous substance within which are several types of granules, i.e., refractive fat globules, various shaped mitochon- 
dria and other granules. The nucleus appears as a finely granular body surrounded by a definite nuclear wall with one or more nucleoli. The nucleolus is never a round compact body, but instead is a coarsely granular ragged body, often large in proportion to the size of the nucleus. The nucleolus can readily be seen with the low power even when the outline of the nucleus cannot be distinguished. At one side of the nucleus there is usually present the central body (idiozome).

When permanent preparations were desired the cover-slip was removed from the vaseline ring and the entire culture fixed to the cover-slip by means of osmic acid vapor. After fixation the explanted piece was often torn off from the cover-slip, leaving the new growth, in order to facilitate certain staining processes. Since the growth is very thin it was unnecessary to cut sections. The cover-slip with the fixed growth was treated as one would sections on a slide.

\section{FIXATION}

The entire process of fixation can be watched and studied upon any cell, as, for example, one that has been under observation for some time. While the preparation is observed under the microscope some of the fixing solution can be introduced into the cavity of the slide through an opening made in the vaseline ring, which seals the coverslip to the slide. The specimen can be fixed with either vapor or fluid. If a vapor is used, as of osmic acid, a small drop of a 2 per cent solution of osmic acid is introduced on the bottom of the cavity so that it does not come in contact with the hanging drop. If a solution is used, enough is introduced to fill the entire cavity and mix with the hanging drop.

The vapor from a freshly made 2 per cent osmic acid solution gave the best results, and when used with care resulted in a fixed cell, which more closely resembled the living cell than any other method we have used. The osmic acid vapour seems to cause a precipitation of the cell structures in the form of minute granules. Even after such fixed specimens are stained by means of iron hematoxylin the general character of the cyto- 
plasm and nucleus are not noticeably altered except for the staining.

B. F. Kingsbury ('12) states that according to Rawitz ('07), Kollarewsky ('87) and Eisen ('00) osmic acid does not preserve nuclear details. So far as can be seen from our material the living cell exhibits few nuclear details and even osmic acid vapor differentiates more clearly the nuclear structures than they can be distinguished in the living cell.

The mitochondria are so well fixed by osmic acid vapor or by a fixing solution which contains osmic acid that it has been suggested that the mitochondria may be artifacts due to osmic fixation. Vapor from strong formalin which has been carefully neutralized (Mann '02 and also Bensley '11 recommend that formalin be freed from acid by careful neutralization and redistillation) gave good results in regard to fixation not only of the mitochondria but of all cellular structures. Unfortunately, the mitochondria did not stain well after formalin fixation. Iodine vapor from a crystal of iodine often afforded good results in regard to the spindle fibers and also the mitochondria, especially so when followed by Bensley's anilin fuchsin, methylene green stain, but iodine was an uncertain fixative. Osmic acid solutions do not give as uniformly good results as the vapor.

Any fixing solution which contained acid (acetic, hydrochloric, sulphuric, etc.) proved useless as a fixative for tissue cultures. The vapor from such acids coagulated the entire cell before the fluid touched the preparations. The mitochondria rapidly changed into small granular rings, which later were completely lost in the coagulated network of cytoplasm. The nucleus lost its homogenous finely granular structure and a coarse network appeared. The nucleolus became a small round body. This resembles closely the usual textbook figure of a cell, which by long association one has come to believe represents a cell but which actually resembles the living cell not at all.

When a living cell (fig. 2 a) was exposed to the action of vapor from 2 per cent glacial acetic this coagulation effect was soon apparent, as shown in figure $2 \mathrm{~b}$. The cytoplasmic and nuclear networks rapidly appeared while the mitochondria, which 

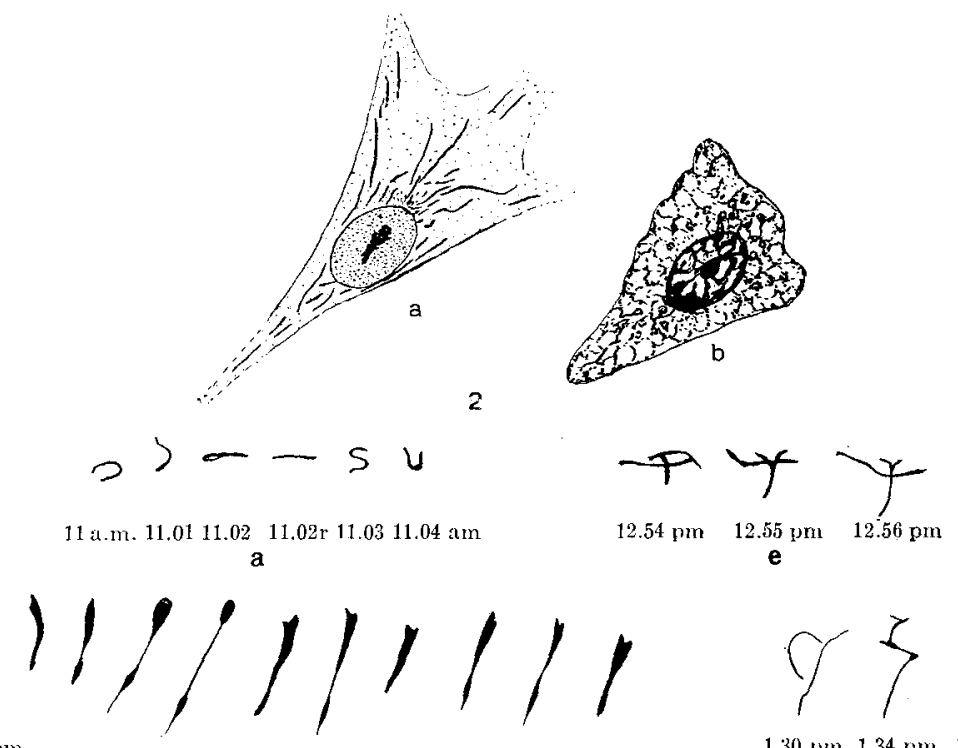

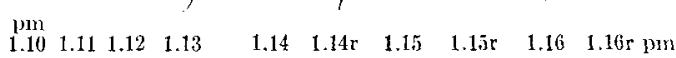

b

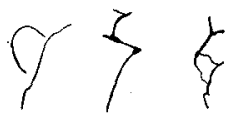

$1.30 \mathrm{pm} \quad 1.34 \mathrm{pm} \quad 1.36 \mathrm{pm}$ d

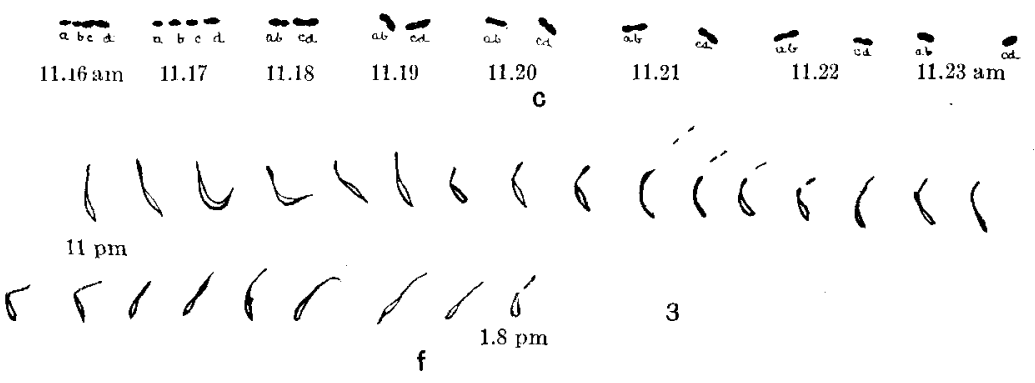

Hig. $2 A$, sketch of living cell with nucleus and mitochondria, the cytoplasm should be homogenous. $b$, the same cell after exposure to the vapor of 2 per cent acetic acid; both cytoplasm and nucleus show reticular structure due to coagulation; the mitochondria are destroyed except for a few granular remains.

Fig. 3 Changes in shape of mitochondria as observed in living cells; $a$, changes by bending during a period of 4 minutes; $b$, by shortening and elongating and shifting along the mitochondrium of the mitochondrial substance, time 6 minutes; $c$, by fusion of granules; in the course of 7 minutes the four granules $a, b, c, d$ became fused into two granules $a b$ and $c d ; a, b, c$ from a 2-day culture of mesenchyme from a $4 \frac{1}{2}$-day chick; $d$, changes in shape and fusion of mitochondria to form network in the course of 6 minutes; $e$, changes in shape and fusion, 2 minutes; $f$, changes in form of a single mitochondrium during a period of 7 minutes; $d$, $e$ and $f$ from a 3 -day culture of mesenchyme from a 4-day chick. 
were clearly seen in the living cell as long rods and threads rapidly disappeared. Brunn ('84) found that the Eberth bodies, which have since been shown to be mitochondria, are dissolved by acetic acid. Duesberg ('11) states the fact that they are destroyed by acetic acid to be one of the criteria for mitochondria. Prolonged fixation in osmic acid after the osmic vapor has already fixed the preparation did not cause any distortion of the nucleus or the cytoplasmic structures. The mitochondria became somewhat blackened and the fat globules were first yellow-brown and later became a dark brown. Even after a month no change appeared in the cytoplasm which in any way indicated the presence of a canilicular apparatus as was found in certain other cells by Kopsch ('02), Sjovall ('06), and Cowdry ('12).

A careful study of the living cell together with a study of the effect of various fixatives shows that while the mitochondria are only successfully fixed by osmic acid, they are by no means artifacts due to osmic acid fixation.

\section{MITOCHONDRIA}

The mitochondria are always present in the living cells of the tissue cultures and after some experience can be easily recognized. They are never as conspicuous, however, as the fat globules or the nucleus. The mitochondria are slightly refractive bodies which vary greatly in shape, size, and position. In the living cell these bodies are never quiet, but are continually changing in shape, size, and position. Often as many as fifteen or twenty shapes may be exhibited by a single mitochondrium within as many minutes (fig. 3). This extreme plasticity of the mitochondria is a very important characteristic and was shown in every preparation examined. It is certainly a feature which must be reckoned with in any attempt to classify or to analyze their behavior from fixed material.

The chaotic condition of the literature in respect to the terminology and criteria for mitochondria and other cytoplasmic bodies renders it difficult often to correlate our findings with 
those of other observers. It is important then that we should as far as possible submit the bodies herein under consideration to already established criteria for mitochondria.

While these bodies fulfil Benda's ('99) original criterion for mitochondria in embryonic cells in that they stain blue with alizarine, we have made no effort to fulfil Montgomery's ('11) eriterion that they must show an unbroken cycle from egg to somatic cell to anlage sex cell and back to the fertilized egg. They do, however, correspond with Duesberg's ('11) criterion for mitochondria in the adult cell, in that they are seen in the fresh preparation, dissolved by acetic acid, preserved by osmic acid, and stain by the same dyes as the mitochondria in embryonic cells, that is, green with Janus green in the fresh preparations (Michaelis '99, Laguesse '99, Bensley '11, Cowdry '12); stain blue with Benda's stain (Benda '03, Meves, '08, Duesberg '09); red with Bensley's anilin fuchsin, methylen green stain (Bensley '11, Cowdry '12), and black with Heidenhain's iron hematoxylin.

Janus green caused the death of the growth after a few hours, and frequently the mitochondria separated into granules (fig. 21). For this reason Janus green was used only to identify various granules as mitochondria but never for any observations upon the changes in shape, size or quantity of mitochondria.

These bodies have been given various names--mitochondria and chondriomiten by Benda; chondrioconten, chondriosomen, chondrion and plastosomen by Meves; plasmafaden, plasmakören by Retzius; paramiton or miton by Flemming; microsomen by Van Beneden; granules and filament by Altman, etc.

\section{Position of mitochondria}

Great variation occurs in the arrangement of the mitochondria even in the same kind of cells in the same preparation, not only in the living but also in the fixed preparations. It is not uncommon for the mitochondria to be more or less evenly scattered throughout the cytoplasm and the various processes of the cell. They have been observed even in the extremely 
slender processes that are scarcely larger in diameter than a mitochondrium. This rather uniformly scattered arrangement usually occurs during mitosis and here likewise the cell processes may contain mitochondria. The spindle area is usually free from mitochondria (figs. 4, 15, 16, 17). Infrequently in the late anaphase the mitochondria may collect along the plane of division. In elongated cells the mitochondria are usually arranged at either end of the nucleus with their long axis more or less parallel to the long axis of the cell. However, in many of the cells the mitochondria are more numerous about the nucleus or about the central body than towards the periphery of the cell, where they may be scattered or entirely absent (figs. 4, 5, 12, 17). The central body is an extremely finely granular body at one side of the nucleus and has been so-called by us because the mitochondria frequently radiate around this body and because it is a non-committal term. Usually the idiozome (or nebenkern, for discussion of correct terminology see Wilson '11) can be seen within this body and occasionally the centrasome can be made out within the idiozome. The central body is more clearly seen in the living cell than in the fixed cell, but in some cells this body cannot be distinguished and the mitochondria appear more or less radially arranged around the nucleus. At times the mitochondria may be confined to one side only of the nucleus, usually the side on which lies the central body. This radial arrangement about the central body has been described by Eberth (66), Vejdovsky ('07), Meves ('09), Veratti ('09). In some preparations this arrangement is so marked that one cannot but wonder if there is not some definite relationship between the two, and it is not difficult to understand why Vejdovsky ('07) believed that the mitochondria were products of the activity of the centrasome.

The mitochondria, however, are continually altering their position, not only in relation to the nucleus and central body but also in relation to each other. They seem to be continually emerging from the mass near the nucleus or near the central body and to migrate out towards the periphery. Also those towards the periphery often return to the central mass. There 

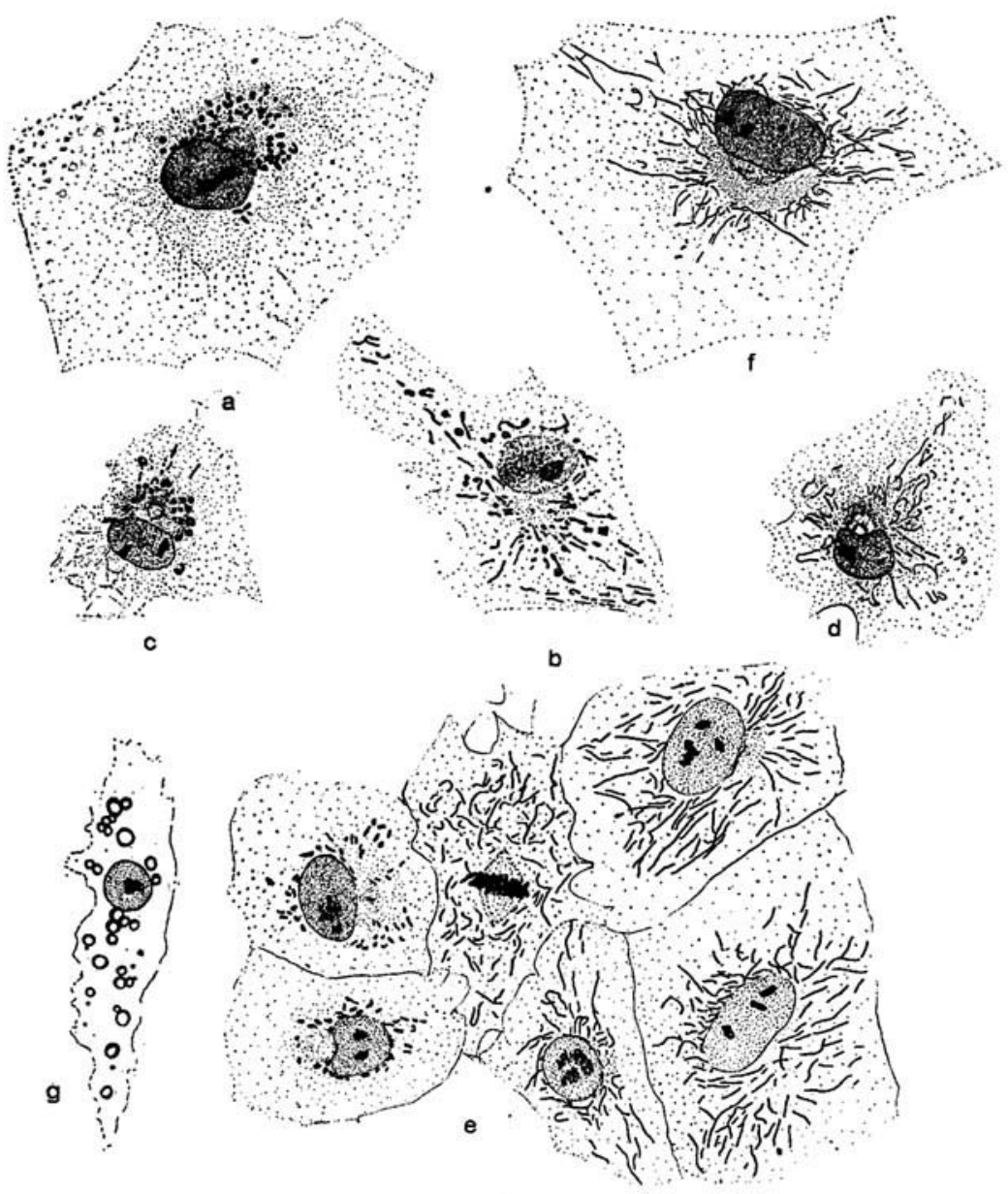

4

Fig. $4 A, b, c, d, e$, cells from a 2-day culture of heart from a 5-day chick. $a$, cell with 69 mitochondria of granular type, somewhat radially arranged about the central body. $b$, cell with 125 mitochondria of very different shapes and sizes, about the central body and scattered through the cytoplasm. $c$, cell with 37 mitochondria about the central body, mostly granular in type; $\times 1080$ diam. $d$, cell with about 90 mitochondria about nucleus and central body, mostly rodand thread-shaped; $\times 540$ diam. $e$, group of six adjoining cells; as in $a$ the cells with granular and short, rod-shaped mitochondria show the latter arranged about the nucleus and central body; one cell contains 40 and the other 54 mitochondria of the short and long rod- and thread-shaped types, which are arranged more 

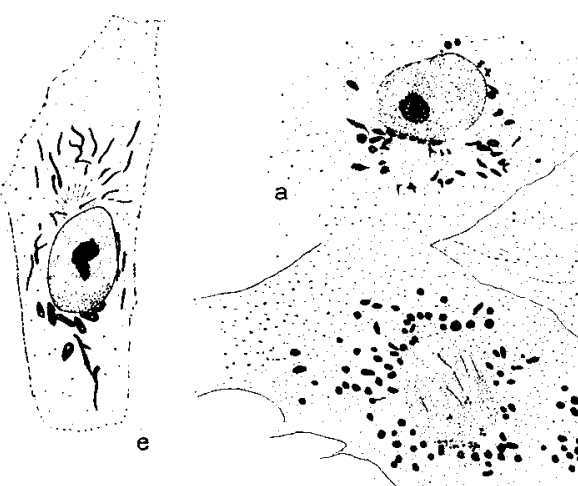

a
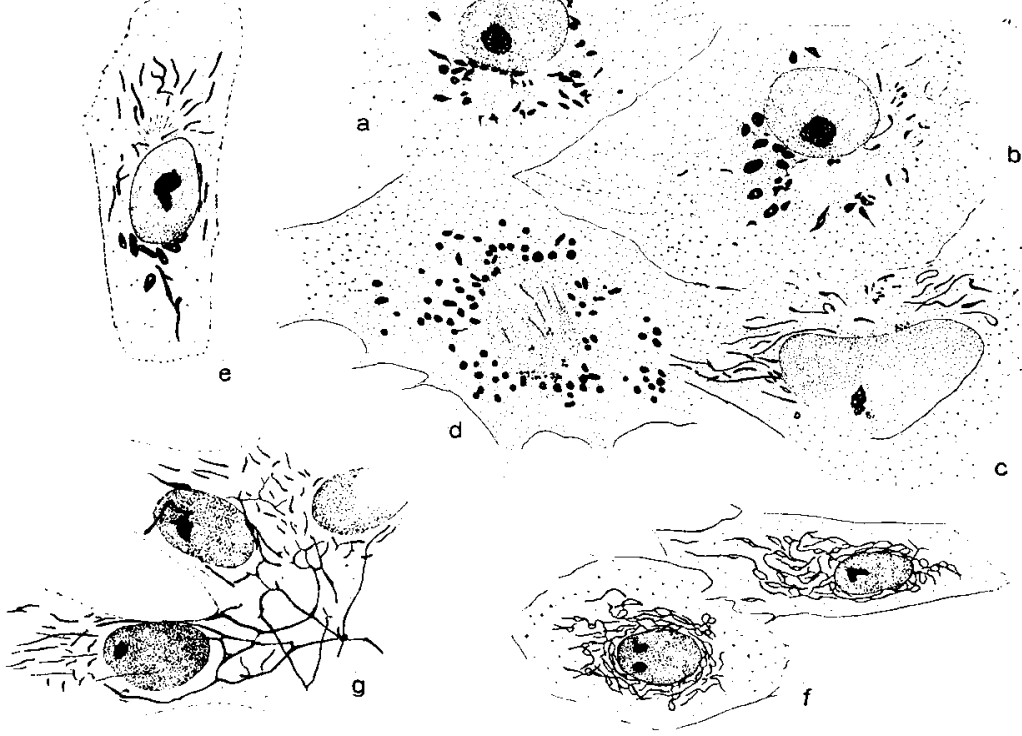

5

about the nucleus and central body; the dividing cell has 118 mitochondria which are scattered more evenly through the cytoplasm than in the other cells; $\times 790$ diam.; osmic acid vapor and iron hematoxylin; $f$, cell from a 2-day culture of heart from a 6-day chick cell with 152 mitochondria, mostly rod-and threadshaped, arranged about nucleus and central body; $\times 790$ diam. $g$, cell from a 2-day culture of heart from a 4-day chick. Only two cells in entire culture show these ring-formed mitochondria and in these two the cytoplasm was abnormal, perhaps dead. Bensley stain; $\times 790$ diam.

Fig. $5 A, b, c, d$, four adjoining cells from a 2-day culture of heart from a 5 -day chick; $\times 790$ diam. The resting cells, $a, b$ and $c$, have 47,51 and 48 mitochondria respectively, while cell $d$ in early prophase has 89 . These cells exhibit great variety in the shapes of the mitochondria; small and large granules, spindles, short rods, long rods and threads are present; the mitochondria are somewhat more scattered than the cytoplasm in cell $d$. $e$, cell with 38 mitochondria which vary greatly in size and shape; from the same specimen; $\times 540$; osmic acid vapor and iron hematoxylin. $f, g$, mesenchyme cells from '2-day cultures of intestine from a 7-day chick embryo; $f$, many of the mitochondria are united in networks; $\times 540$ diam.; $g$, some of the mitochondria branch and anastomose to form a complicated network which appears to extend from one nuclear area to another, where the cells form a syncytium; $\times 790$ diam.; only a portion of the cells and network is shown; osmic acid vapor and iron hematoxylin. 
is probably no relation between the movement of the cell and the movement of the mitochondria, for the cell processes change their position so slowly that there is often no noticeable change for several hours, while the mitochondria change position rapidly and continually.

Occasionally in a syncytium of cells a mitochondrium may pass over the cytoplasmic bridge from one cell to another (fig. $5 \mathrm{~g})$. In some cases a mitochondrial thread may pass over the bridge into another cell and later return.

What is it that governs the arrangement of the mitochondria? Is it the shape of the cell, the influence of the central body or of the nucleus, the internal structure of the cytoplasm, or do the metabolic activities of the cell govern the size, shape and arrangement of the mitochondria?

\section{Shape of mitochondria}

The mitochondria exhibit extraordinary diversity of form often in the same preparation, even in adjoining cells of the same type (figs. 4, 5). Not infrequently a single cell may contain mitochondria of diverse shapes (fig. 5 e). These different mitochondrial shapes may be more or less localized in different parts of the cytoplasm (fig. 5 e) or may be more or less mixed together (fig. $4 \mathrm{~b}$ ). The extraordinary diversity in form of the mitochondria shown by cells of the same type lying side-by-side in the same preparation is sometimes very striking. Such differences occur in the young growing cells after division, in older resting cells and even during the various stages of mitosis. Again, we may find in the same preparation groups of cells in one part of the growth, that have very similarly shaped mitochondria, while in another part practically all of the cells may have quite differently shaped mitochondria. In such preparations all gradations in shape and size, from minute granules to larger and larger ones, or from rods to threads of various lengths, or threads and networks, etc., can be seen in adjoining cells of the same type or even in the same cell. Just as the fixed preparations show such gradations, we find that all sorts 
of transformations from one shape into another can be watched in the living cell.

Mitochondria of various shapes have been described by other observers, and so definite did some of the shapes appear to be that they were given various names, which today are without much significance. Nevertheless, it is convenient to classify mitochondria as follows (fig. 10).

$\begin{array}{ll}\text { Small granules } & \text { Threads } \\ \text { Dumb-bell-shaped granules } & \text { Loops } \\ \text { Spindle-shaped granules } & \text { Rings } \\ \text { Large granules } & \text { Network } \\ \text { Rods } & \end{array}$

The degenerate mitochondria also show more or less definite shapes (fig. 13).

Mitochondria continually change shape as by bending in various directions (fig. $3 \mathrm{a}$ ), or by shortening and thickening or elongating and thinning (fig. $3 \mathrm{~b}$ ); at times this thickening and thinning seems almost like a pulsation along the length of the mitochondrium. These various shapes of mitochondria are not fixed or constant in any cell. Rods or threads may change into granules; threads may fuse or branch into networks (fig. $3 \mathrm{~d}, 6,7$ ); or granules may fuse to form larger granules (fig. $3 \mathbf{c}$ ). Degenerating mitochondria may separate into granules and vesicles (fig. 13).

Ring-shaped mitochondria are seldom found in these preparations. Occasionally a living cell may contain one or two large or small ring-shaped mitochondria which rapidly change into threads, rods or granules. A few fixed and stained preparations show one or two cells at the periphery of a large growth which contain ring-shaped mitochondria exclusively (fig. $4 \mathrm{~g}$ ). Kingsbury ('11) has suggested the possibility that mitochondria which contain a large amount of lipoid are reduced by osmic acid only at the surface, and the central part later dissolves out, which produces the appearance of rings. These ring-shaped mitochondria can hardly produce fat or lipoid droplets (Dubreuil '11, '13) since they are seldom present in cells in which fat is being formed. 

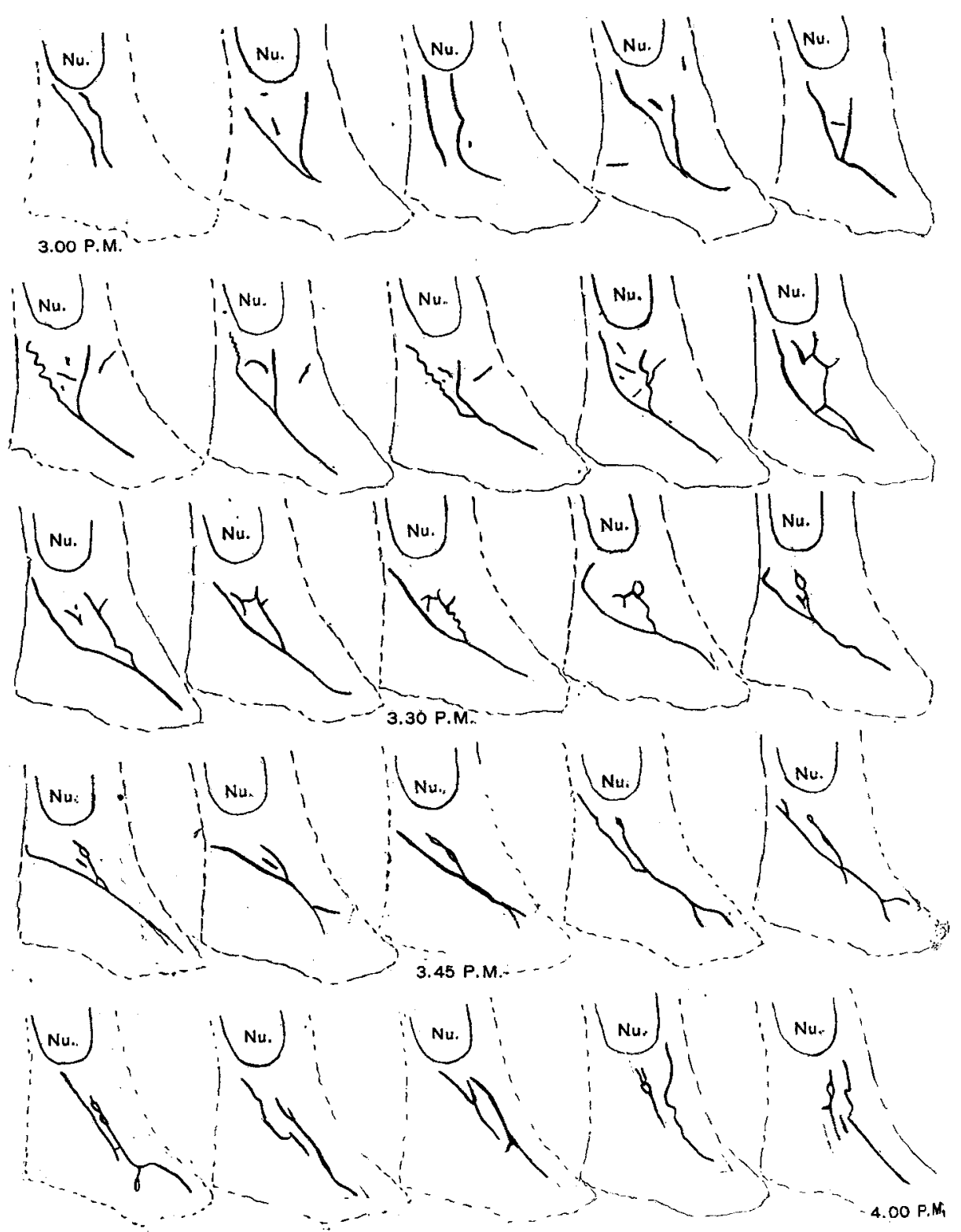

Fig. 6 From a living culture about 24 hours old, of a piece of heart from an 6-day chick, showing branching, fusion and splitting of two or three mitochondria during a period of about 1 hour. 


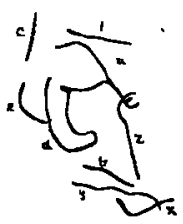

2.40 P.M

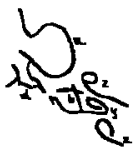

2.46 P.M.

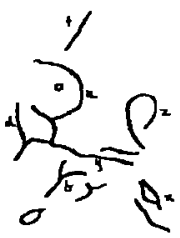

2.55 P.M.

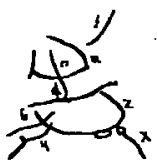

3.00 P.M

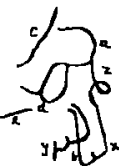

2.42 P.M.<smiles>[GeH2]=[GeH2]</smiles>

2.47 P.M

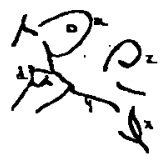

2. 56 P.M.

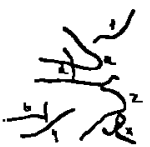

3.02 P.M.

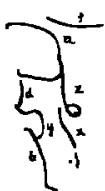

2.43 P.M

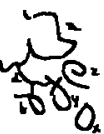

2.4B P.M

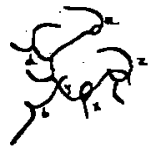

2.57. P.M.

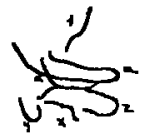

3.05 P.M
2 so P M.

2.58 P.M.

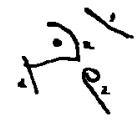

2.46 P.M.

n.

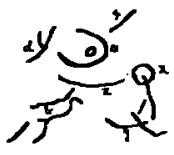

Fig. 7 Changes in shape and anastomoses of a few mitochondria during a period of 25 minutes in a living mesenchyme cell. The changes were so rapid that it was not always possible to draw each mitochondrium; they can be followed by the lettering; 24-hour old oulture from a 6-day chick embryo.

The mitochondria are frequently arranged in the form of a network (fig. $5 \mathrm{f}, \mathrm{g}$ ) which may involve many of the mitochondria or only a few of them. A study of the fixed preparations and especially a study of the living cells shows conclusively that Mislavsky ('11) is correct in his contention that the mitochondria do fuse and branch to form networks. We have observed all 
stages of the formation of network in the living cell. These networks continually change shape (figs. 6, 7). New branches appear, old ones change shape or position or break away, and at times the entire network may break down into loops, threads and granules without any apparent change on the part of the cell. From our observations it appears that the network is

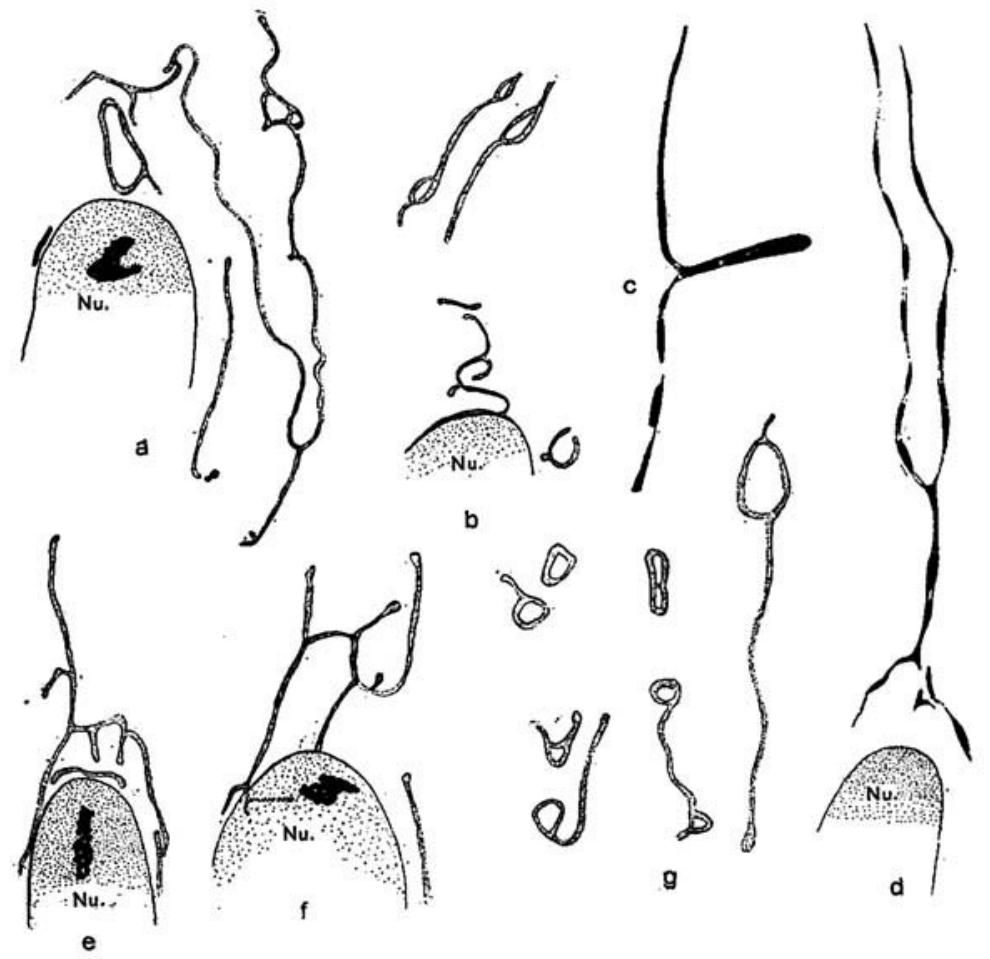

Fig. 8 Mitochondria from a 3-day culture of intestine from a 7-day chick; osmic vapor and iron hematoxylin; $\times 2250$ diam.; various forms of mitochondria, which come from the breaking down of a network, into loops, rings, threads, etc.

very unstable and rapidly breaks down into granules, loops and threads. Figure 8 shows such loops and rings in a fixed specimen.

There has been some discussion as to which shape of mitochondria is the more primitive. Meves ('08) claimed that in the twenty-hour chick embryo the mitochondria are present 
only as very thin threads, but that at forty-eight hours the threads are thicker and also some granules are present. These mitochondria have heavy stained edges with a clear mark substance.

Duesberg ('08) finds the same for the chick, but in the rabbit he describes the mitochondria in the early fertilized egg as small granules, which increase in volume and become large granules at the end of the third day. The large granules have a clear central part and dark outer edge. They flow together and build rods and threads. Rubaschkin ('11) finds only granules in the early guinea-pig development. He claims that the granular form of mitochondria is the most primitive and indifferent form.

So far as could be observed, there is no special difference in the shape of the mitochondria present in the cells of the growth from a piece of a three-day chick embryo from that present in the growth from a piece of ten-day chick embryo. Only those cells show exclusively the small granules, which contain many fat globules or vacuoles. We have observed the cells of a 51 hours growth which contained only the granular type of mitochondria to contain at 70 hours mostly thread types (fig. 9 a-f). The threads were formed by the stretching out of the granules rather than by fusion of granules although such fusion of granules does take place. When a preparation is studied from day to day it is clear that the shape of the mitochondria changes and that no one shape is constant for any one age.

Brown ('13) finds that in the male germ cells of Notonerta the mitochondrial fibers and threads arise in part at least from spherical-shaped mitochondria.

Schaxel ('11) claims that the shape of the mitochondria varies with the method of fixing and staining inasmuch as by the Benda treatment the rod-like forms predominate while after the Altman treatment the granular type predominates. While there have been few observations made as to the effect of various technical methods upon the shape of the mitochondria they appear to be such malleable structures that it is quite probable that their shape could be altered by different methods. 

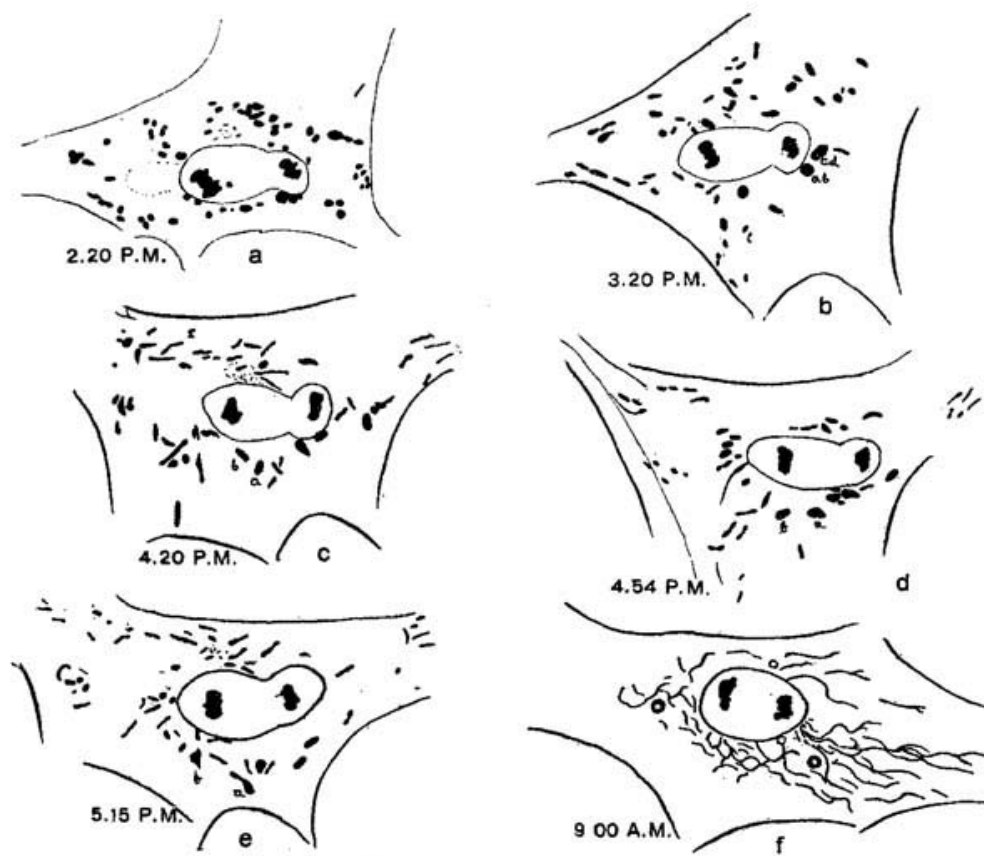

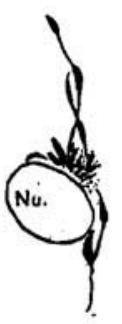

g 4.50, P.M.

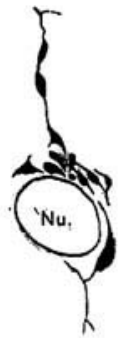

h 4.55 P.M

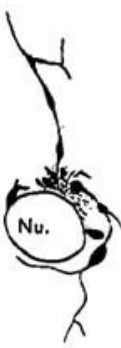

i 500 P.M
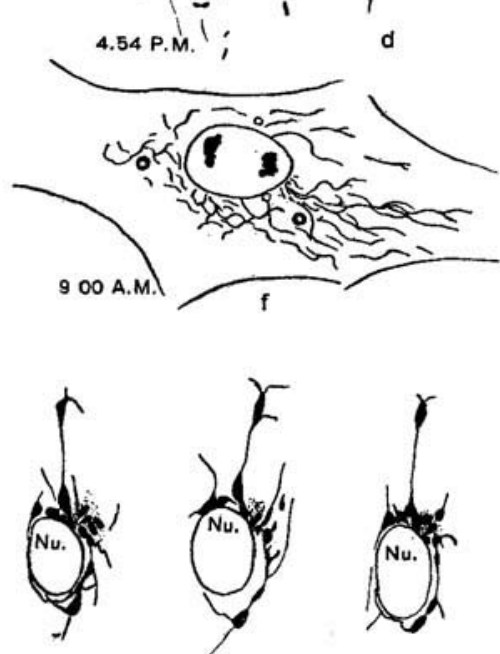

J $5.04 P M$
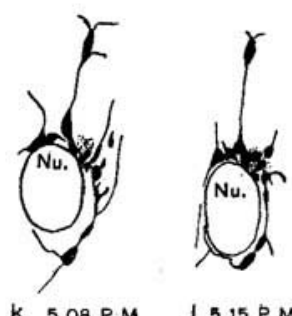

I $5.15 P M$

Fig. 9 Mitochondria in living cell from a culture of heart from a $4 \frac{1}{2}$-day chick. $a$, camera drawing at 2.20 P.M., when culture was 51 hours old; $b$, same cell at 3.20 P.M.; c, at 4.20 P.M.; $d$, at 4.55 P.M.; $e$, at 5.15 P.M.; at this time all the cells had a similar type of mitochondria; $f$, camera drawing at 9.20 A.M. of next day, culture 70 hours old. All the cells in the culture had the same type of mitochondria as in $e$. At 4 P.M. most of the cells began to show signs of degeneration and a fresh drop of Locke's solution was put on preparation; the thread-like mitochondria, as seen in $f$, began to fuse into large spindle-shaped masses near the nucleus and central body, as in $g$, where all the mitochondria now present at 4.50 P.M. are shown, and the changes which they underwent during the next 25 minutes are in this particular cell shown in $h, i, j, k$ and $l$. 


\section{Size of mitochondria}

The mitochondria vary so greatly in size (fig. 10) that were it not for prolonged study of them and the use of a specific vital stain such as Janus green it would be difficult to believe that they all belong in the same class of granules. Even in a single cell great variation occurs from very minute granules which are scarcely visible to relatively large masses (figs. $4,5,9$ ).

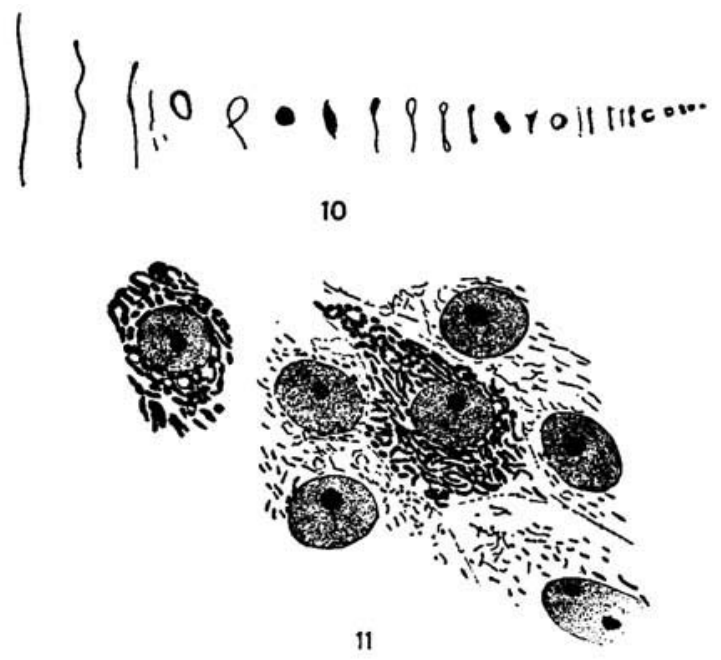

Fig. 10 Camera lucida drawings of mitochondria of various sizes and shapes from different cells and specimens; osmic acid vapor and iron hematoxylin; $X$ 790 diam.

Fig. 11 Endodermal cells from 3-day culture of allantois from a 7-day chick; Bensley's aniline fuschsin methylene green stain; $\times 790$ diam.

Occasionally a cell is seen in which all the mitochondria appear to be swollen up and much larger than those in the surrounding cells (fig. 11). To what this is due is not known.

A mitochondrium under observation frequently seems to change in size as well as shape, but so far no micrometer measurements have been made to determine this point. Definite increase in size has frequently been seen, due to fusion of two granules to form a larger granule or to fusion of rods into threads; and occasionally all the mitochondria in the cell may become col- 
lected in several very large granules (fig. 9). In certain pathological conditions Barratt ('13) has found that the mitochondria become abnormally large and stain clearly.

\section{Number of mitochondria}

The number of mitochondria varies greatly in cells of the same kind in the same preparation (fig. 12) and in different preparations (figs. 4, 5, 12). Numerous counts of the mitochondria in the same kind of cells in the same preparation show that there is no one number of mitochondria peculiar to any one kind of cell or to any one stage in the development of the cell. The number of the mitochondria appear to decrease and to increase under various conditions. This may result from fusion or division of the mitochondria without much change in the quantity of mitochondrial substance; or this may be accompanied by a corresponding increase or decrease in the amount of mitochondrial substance, independent of any fusion or division of the already existing mitochondria. This would indicate that some of the mitochondria may at times entirely disappear and that possibly new ones may arise de novo in the cytoplasm. Sometimes most of the cells in a growth undergo such changes. When observed on one day they may have rather few mitochondria, while on the following day most of the cells may contain a marked increase in the number of mitochondria, or the opposite phenomenon may take place. This may or may not be accompanied by a corresponding change in the quantity of mitochondrial substance. Prolonged action of heat causes a decrease in the size and number of the mitochondria, and it is hoped that further experimental work will determine what conditions cause such changes in the ordinary cultures.

\section{Quantity of mitochondria}

By the quantity of mitochondria we mean the total mass of the mitochondrial substance within a cell. This can only be roughly estimated, as some cells with many very small mitochondria have a smaller quantity of mitochondrial substance than others with fewer but larger mitochondria. However, in 


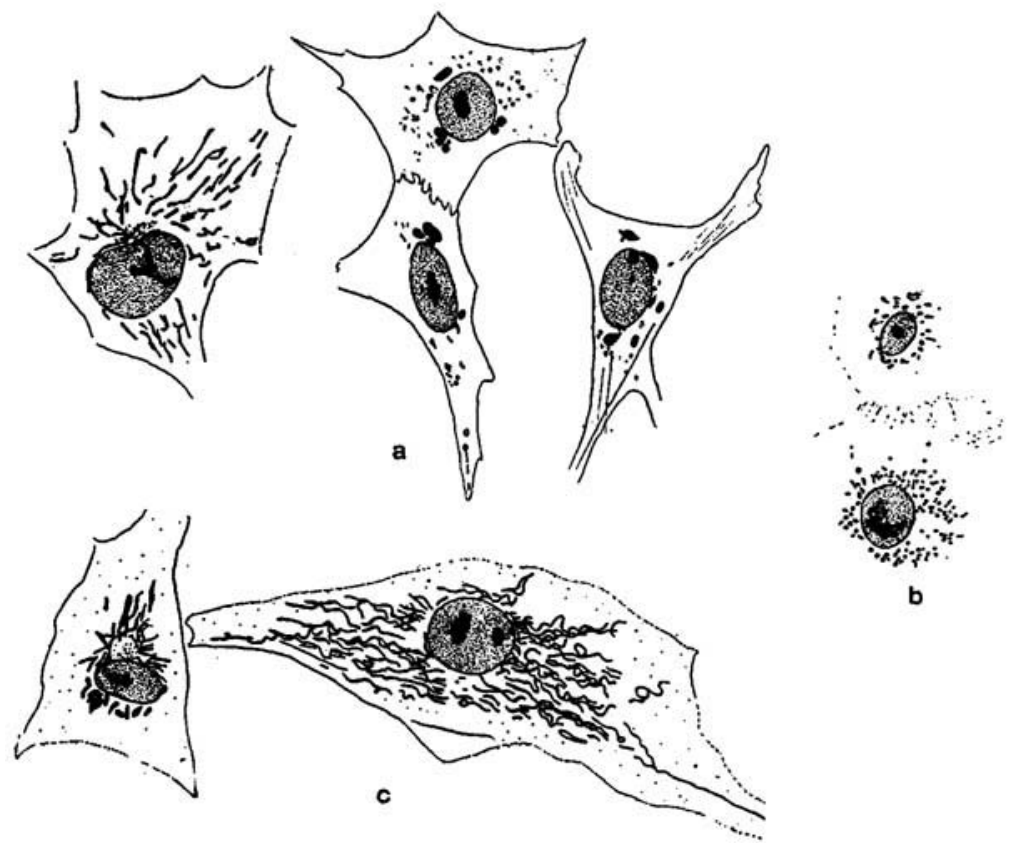

Fig. 12 A, mesenchyme cells from a 2-day culture of intestine from a 5-day chick, showing marked differences in shape, size and number of mitochondria. The four cells have 74, 8, 27 and 6 mitochondria; Bensley stain; $\times 790$ diam.; $b$, two adjoining cells from a 2-day culture of heart from a 7-day chick; granular type of mitochondria, one cell has 38 and the other 111 mitochondria. Osmic acid and iron hematoxylin; $\times 540$ diam.; $c$, two endodermal cells from a 2-day culture of allantois from a 4-day chick; the larger cell contains about 128 and the other 27 mitochondria; Bensley stain; $\times 790$ diam.

many cases of adjoining cells (figs. 11, $12 \mathrm{~b}$ ) or of the same kind of cells in different parts of the preparation (fig. $12 \mathrm{c}$ ) there can be no doubt that the quantity of mitochondria is markedly increased or very much decreased. This increase in the quantity of mitochondria is most marked in a few scattered cells in the growth from a piece of allantois (fig. 11).

Cells with few mitochondria do not necessarily have larger mitochondria and there seems to be no definite relation between size and number or number and quantity. The quantity in the cell differs so widely that it has so far been impossible to connect the quantity of mitochondria with any one factor. Possibly it is dependent upon the metabolism of the individual cell. 
This is also true of cells undergoing division, for there seems to be no amount of mitochondria characteristic of any one phase of division. Also the variation in the quantity of mitochondria present in any one phase of division is considerable, as can be seen (figs. 14, 15, 16). Daughter cells usually have a smaller quantity of mitochondria than the metaphase cell or than the resting cell (fig. 17).

As to the question whether the amount of mitochondria increases during mitosis it is impossible to state. So far, we have only one definite observation that this is true. In this case the living culture was subjected to a temperature of $46^{\circ} \mathrm{C}$. for two hours, during which period the mitochondria decreased decidedly in number and size. Two cells which were under observation suddenly began to pass into prophase and during this process the number of mitochondria in these two cells increased until they contained more than they had before the experiment was begun. Although several subsequent experiments with increased heat caused a decrease in the quantity of mitochondria no cell division was observed.

No agent but heat has so far been observed which caused a change in the amount of the mitochondria without injury to the cell. However, it is evident that certain metabolic conditions must cause a change in the quantity of mitochondria.

\section{Relation between position, size, number and quantity of mitochondria}

No definite relation between the position, size, number and quantity of the mitochondria has been observed in the cells of the tissue cultures, still there is a more or less marked manner in which the mitochondria occur in the cells. Frequently the long threads or short rods are plentiful and scattered throughout the cytoplasm with or without a definite central body. When the mitochondria are in the form of large granules and thick rods they are fewer in number and are arranged more or less radially around a central body. When only a very few mitochondrial granules are present they are usually of the large granule type. 
All phases in the development of the cell, i.e., daughter cell, growing cell, resting cell and dividing cell can be found with any one of the above combinations of the mitochondria. However, it must not be forgotten that many cells contain part of one kind of mitochondria and part of another and that any one shape of mitochondria may turn into another at any time during observation, and that no one shape of mitochondria remains as such for a very long interval of time, but changes into another.
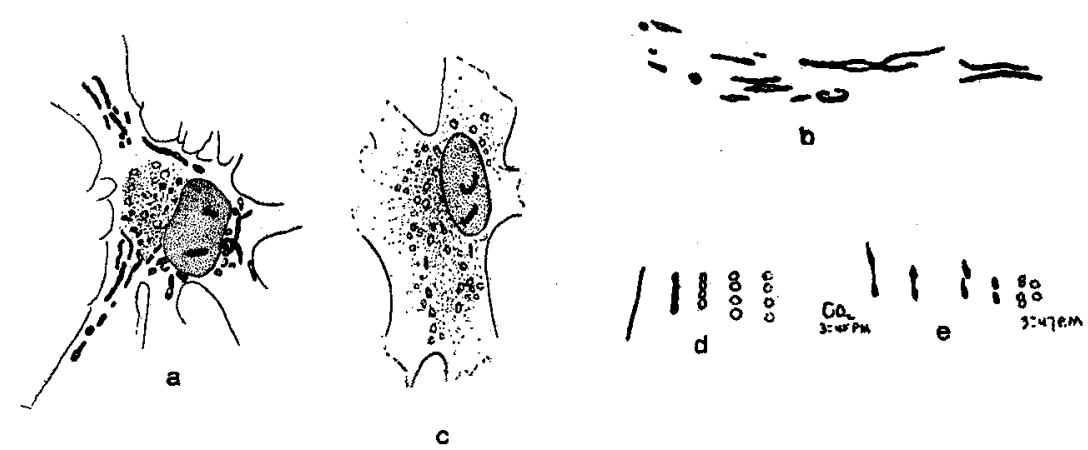

Fig. 13 A, cell from a 2-day culture of heart from a 7-day chick; practically all the mitochondria are degenerated, those in the region of the central body show most advanced stage of granular rings; $\times 790$ diam.; $b$, degenerating mitochondria from mesenchyme cell of a 2-day culture of intestine from a 4-day chick; $\times 920$ diam.; $c$, cell from a 2-day culture of heart of a 5-day chick; all the mitochondria have degenerated into granular rings; osmic acid vapor and iron hematoxylin; $\times 790$ diam.; $d$, process of degeneration in a single mitochondrium produced by the action of acetic acid vapor on a living cell; $e$, effect of $\mathrm{CO}_{2}$ on another mitochondrium in 2 minutes.

\section{Degenerate mitochondria}

Degenerate mitochondria of various shapes are occasionally found in these preparations (fig. 13). A study of the cells of the older growths shows that all the mitochondria do not necessarily degenerate at the same time. Some cells are found which contain many normal mitochondria, some partly degenerate, and others entirely degenerate. 
This degeneration appears first in the mitochondria around the central body and later in those scattered at the periphery (fig. 13 a).

The process of degeneration of the mitochondria can be most successfuily observed when produced by some outside agency such as carbonic acid gas or vapor from a weak acid solution (fig. $13 \mathrm{~d}, \mathrm{e}$ ). When the death of the cell is produced experimentally the mitochondria become first a series of granules which soon become slightly vesicular although at this stage they still stain in the characteristic manner. Then these vesicles separate and rapidly become small, finely granular rings or shadows. These no longer stain like mitochondria but more like the cytoplasm, i.e., brownish green with Bensley's anilin fuchsin, methylen green or pale gray with Heidenhain's iron hemotoxylin, and in the living cell the Janus green does not stain them green. It is apparent that some change has taken place which has completely changed not only the morphology but also the composition of the mitochondria.

These degenerate mitochondria correspond in many ways to the "grains du segregation" described by Dubreuil in the lymph cells, but are unquestionably degenerate mitochondria, and they can be produced in any cell of these growths by means of various agents such as carbonic acid gas, chloretone, acid vapor, hydrogen peroxide and potassium permanganate.

Meves ('10) and Duesberg ('10) simultaneously found that poorly fixed mitochondria show granulation and small bladder forms. Other observers have found that granulation is due to delay in fixation after death or to disease, as Mayer and Rathery ('07) experimental polyuria; Takaki ('07) polyuria or prolonged fast; Policard ('10) experimental poluria and after injection of phlorizin; Policard and Garnier ('07), Cesa Bianchi ('10), Heidenhain ('11) also obtained similar results.

Beckton ('10) claims that in a certain tumor no mitochondria were present in the tumor cells. In view of the observations of Beckwith ('14) it may be possible that certain cells can exist without mitochondria, but it seems more probable that the apparent lack of mitochondria in the tumor cell described by 
Beckton may have been caused by delay in fixing the material so that the mitochondria became degenerate, or the mitochondria may have been present only as degenerate structures which did not stain.

\section{Mitochondria in mitosis}

Naturally, the question at once arises: What is the role of the mitochondria during division of the cell? Many observers believe that the mitochondria form a palisade about the spindle during late anaphase and then divide and one-half of each mito-
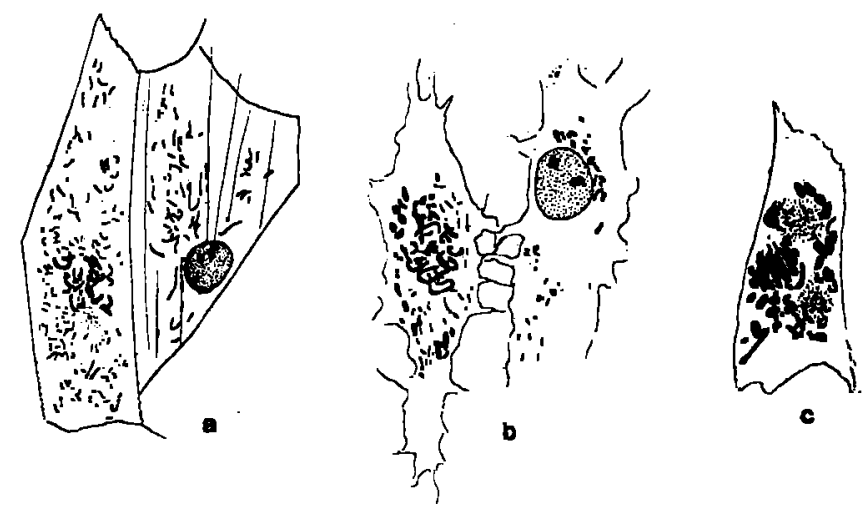

Fig. 14 Arrangement of mitochondria in the prophase stage; $a$, from a 3-day culture of intestine from an 8-day chick embryo; $\times 1080$ diam.; $b$, from a 3-day culture of intestine from a 7-day chick; $\times 790$ diam.; $c$, from a 2-day culture of heart from a 5-day chick embryo; $\times 540$ diam.

chondrium passes to each daughter cell (Benda, Duesberg, Meves, etc.). Meves ('13) in his work on ascaris egg goes so far as to state that not only are the mitochondria present in the egg and spermatozoon, but also that the male mitochondria are carried into the egg by the spermatozoon and so each egg receives not only female but also male mitochondria and the granules resulting from the fusion of the male and female mitochondria are distributed to each cell of the embryo. In view of the behavior of the mitochondria Meves suggests that they may play a part in inheritance. 
A study of the fixed specimens seems to show that the mitochondria retain somewhat their original character and shape during mitosis (figs. 14-17). They are, however, almost always shorter and more scattered through the cytoplasm than in the surrounding cells (figs. 4, 5, $14 \mathrm{a}, 15 \mathrm{~b}, \mathrm{~d}, 17,18$ ). There are usually as many and often more mitochondria in the early stages of the dividing cell than in the neighboring cells (figs. 4, 5, $14 \mathrm{a}, \mathrm{b}, 15 \mathrm{~b}$ ).

There is no indication in the fixed specimens of any arrangement of the mitochondria about the spindle in such a manner that they would undergo division into two parts in the plane of cleavage of the dividing cell. On the other hand, all of our specimens seem to show that the mitochondria tend to become more evenly scattered through the cytoplasm during division, and those that happen to be on either side of the cleavage plane are carried into the respective daughter cells.

Since each daughter cell contains only about one-half the number of mitochondria found in the mother cell at the time of division we must assume that there is an increase sometime during the life of the cell between one division and the next, otherwise the number would rapidly decrease during each successive division. Now the question is: When does this increase take place? Is it during the so-called resting period, or during mitosis? In some of the fixed preparations where mitotic figures, daughter cells and young growing cells are numerous, it is possible to arrange cells in a series according to the stage of recon-

Fig. 15 Arrangement of mitochondria during metaphase; $a, b, c, f$, cells from 2-day cultures of heart from 5-day chick embryos; $d$, $e$, cells from a 3 -day culture of intestine from an 8-day chick embryo; $\times 540$ diam.

Fig. 16 Arrangement of mitochondria during anaphase and telephase and young daughter cells, $a, b, c$, from a 3-day culture of intestine from an 8-day chick; $\times 540$ diam. Cell $a$, anaphase has 156 mitochondria, the two daughter cells, $b$, have 122 and 125 each, while the older daughter cell, $c$, has 151 mitochondria; the neighboring adult cells in this region have been 70 to 160 mitochondria; $d, 3$-day culture of intestine from a 7-day chick; the two daughter cells with the smaller dark nuclei have 92 and 49 mitochondria, while the adjoining resting cells have only 77 and 48 mitochondria each; $\times 790 ; e$, daughter cell from a 2-day culture of heart from a 5-day chick, with very different type of mitochondria; $\times 540$ diam.; osmic acid vapor and iron hematoxylin. 

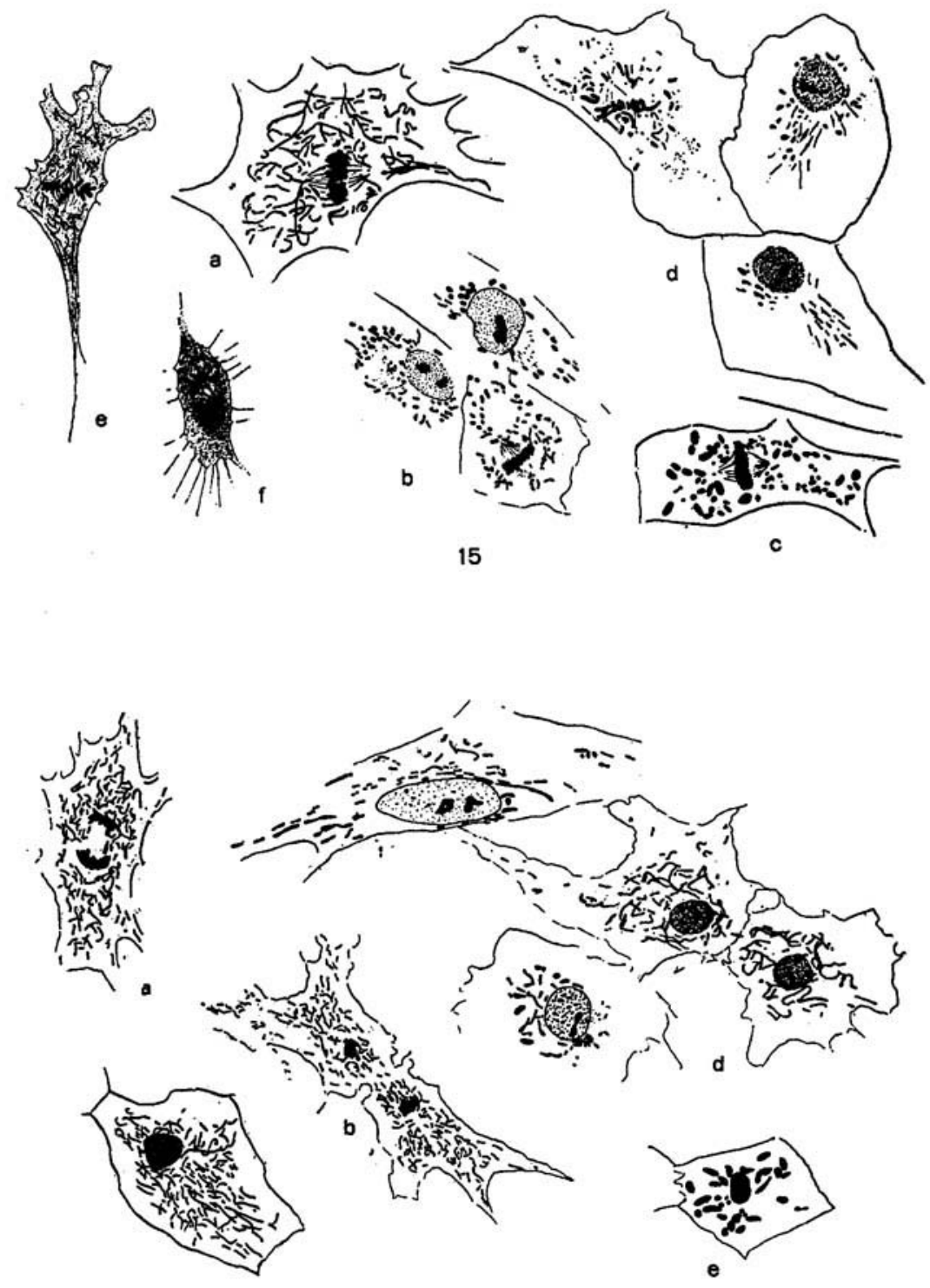
struction of the nucleus, as indicated in figures 17 and 18. The younger nuclei are smaller, darker and more compact and the cells are smaller. The older cells are larger and contain larger nuclei which are less and less deeply stained. In such a series (fig. 17) the number of mitochondria increases from about 40 to 150 . On the other hand, the old resting cell $(k)$ with a very pale nucleus has only 32 . In one series (fig. $18 \mathrm{i}, \mathrm{j}, \mathrm{k}, \mathrm{l}$ ) the number increases from 24 to 140 . In figure 18 one of the two daughter cells (c) has 37 , the dividing cell (a) has 140 , while the two neighboring resting cells (e) and (f) have 39 and 47. Again, in figure 18, the young daughter cells (d, d) have 37 each while older neighboring cells $(\mathrm{g}, \mathrm{h})$ have 56 and 58 each. On the other hand, another dividing cell (b) near this same group has but 60 mitochondria.

From such observations one might conclude that there is a gradual increase in the number and in the size of the mitochondria during the growth period of the daughter cells. The greatest increase both in number and size seems to occur then during the so-called 'resting' period which is in reality a period of growth both for the mitochondria and for the nucleus. On the other hand, while we are unable to determine definitely whether the number of mitochondria actually increases during the early stage of mitosis there are frequently indications that such cells have more mitochondria than mature cells Cell $d$ (fig. 5) early prophase has 89 while the resting cells a, b, c have 47, 51 and 48 mitochondria each. In figure $4 \mathrm{e}$ the dividing cell has 118 while the three neighboring cells have 102, 126 and 62 mitochondria each. The two cells with the larger nuclei are probably older resting cells and each has about the same number of mitochondria as in the dividing cell.

Numerous other specimens seem to show that the dividing cells often have more mitochondria than any of the fullgrown resting cells in the immediate neighborhood. Sometimes this is so marked that there is every indication that the number of the mitochondria in some instances may increase considerably during mitosis. It seems probable thereforee that mitochondria increase in number both during the resting period and during 

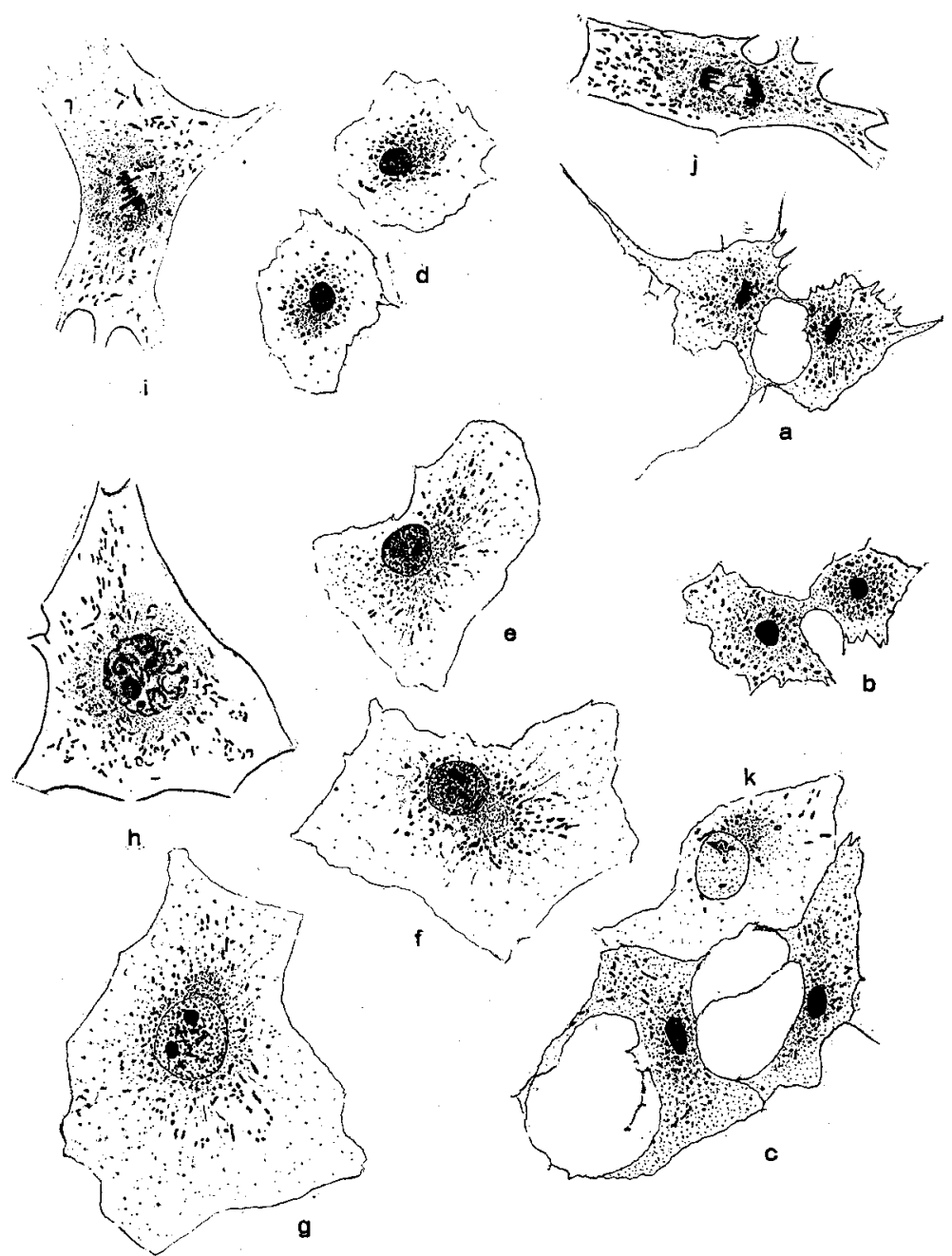

Fig. 17 Cells from a 2-day culture of heart from a 5-day chick embryo; $\times 540$ diam.; $a$, very young daughter cells with 42 mitochondria in each cell; $b$, slightly older daughter cells with 42 and 35 mitochondria; $c$, older daughter cells with 48 and 75 mitochondria; $d$, older daughter cells with 43 and 38 mitochondria; $e$, older cells with 66 mitochondria; $f$, older cell with $96 ; g$, still older cell with 156 ; $h$, prophase with $197(?) ; i$, metaphase with $117 ; j$, anaphase with $174 ; k$, old resting cell with only 32 mitochondria. 
mitosis; perhaps in some more during the resting period; in others more during mitosis and in still others during both periods or only during one. It is very unlikely that one can arrive at a satisfactory solution of such a problem from fixed material, since the bodies we are dealing with are subject to such great changes in number and size during life. The number of mitochondria is not of much value as an indicator of the total quantity of mitochondrial substance.
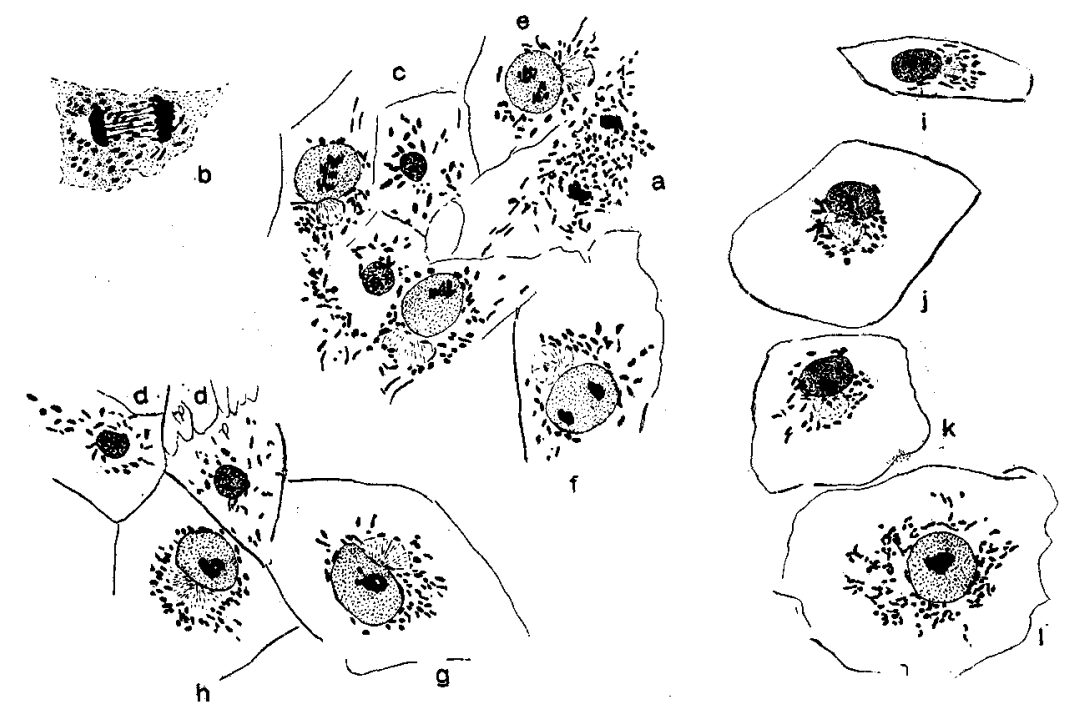

Fig. 18 Cells from a 2-day culture of heart from a 5-day chick; $\times 540$ diam. Cell $a$ in anaphase has about 140 mitochondria, while $b$ has only about 60 , the young daughter cell $c$ has 37 , the two daughter cells $d, d$ have 36 each; the older cells $e, f, g$ and $h$ have $39,47,58$ and 56 mitochondria respectively. In the series $i, j, k, l$, the young cell $i$ has only 24 , the older cells $j$ and $k$ have 41 and 42 , while the mature cell $l$ has 140 mitochondria.

We have indicated that the daughter cells not only have about one-half the number of mitochrondria found in the mature cells, but that the mitochondria are sometimes smaller.

Does the increase in number during the growth period come about through division of preëxisting mitochondria (a process which frequently takes place) or do mitochondria arise de novo? So far as our observations go, either or both processes may occur. 
The only certain method to determine just how and when the mitochondria increase is to follow several living cells through complete cycles. Unfortunately, the cells of tissue culture often round up during late metaphase and anaphase (fig. $15 \mathrm{e}, \mathrm{f}$ ) so that it is impossible, except in a few cases, to follow the individual mitochondrium throughout cell division.

The process of mitosis is an exceedingly slow one compared with that described in other tissues: Prophase 10 to 20 minutes, metaphase and anaphase, 1 to 2 hours; while the period from anaphase including telophase to the daughter cells is an exceedingly short one, never more than five minutes from the time the chromosomes are arranged at the opposite poles of the spindle until the cytoplasm is divided, except for slender processes, and such stages are correspondingly few in number in the permanent preparations.

We have not been able to follow the number of mitochondria through a complete cycle of the cell in the living cultures. We have, however, been able to watch the behavior of the mitochondria during mitosis in a few living cells. Usually the mitochondria are scattered throughout the cytoplasm and remain so during cell division. About one-half of the mitochondria pass to each daughter cell, namely, those which happen to be on one side or the other of the cleavage plane. In two or three cells during late anaphase most of the mitochondria became arranged in rather of a broad zone around the spindle in the area through which the division plane later formed and one-half of the number of mitochondria passed into each daughter cell. There was no indication of any division of the mitochondrial granules; in fact, in one cell it was clearly observed that several thread-shaped mitochondria passed over entire into one of the daughter cells. A division of the mitochondria such as observed by Meves ('08) and Duesberg ('10) was never observed. We find as did Buchner ('09, '10, '11) that this characteristic arrangement of the mitochondria during division of the cell is by no means a constant occurrence.

We have already stated that we are uncertain whether there is an actual or only an apparent increase in the amount of 
mitochondria during mitosis. So far we have only one direct experimental observation to offer, and in this particular case there was an actual increase in the number and possibly also in the quantity. In this experiment the temperature had been raised from 39 to $46^{\circ} \mathrm{C}$. and was retained at $46^{\circ} \mathrm{C}$. for two hours. There resulted a decided decrease in the amount of mitochondria within all the cells. Two cells began to divide. The nuclear wall disappeared, the nucleoli faded and the chromosomes appeared. These cells, which a few minutes before had contained only a very few mitochondria, now became full of short dumbbell-shaped rods, while the resting cells did not undergo any change. So far as could be seen by most careful observation, this increase in quantity of mitochondria was not due to the division of the existing granules.

\section{Mitochondria in different kinds of cells}

Regardless of the fact that the mitochondria constantly change in shape, size and quantity in any one cell, there is a characteristic appearance of the mitochondria in certain kinds of cells, as, for instance, the short, rod and dumbbell shapes are most frequently found in the cells of the endodermal membrane; the long threads, rods and sometimes loops are found more frequently in the connective tissue; the small granules and short rods are frequent in nerve fibers and cells, and are often much smaller than those of the connective tissue cells over which the nerve fiber passes; a striated arrangement together with scattered granules is characteristic of the fibroblasts; and the large granules are more frequently seen in the heart and smooth muscle syncitium than in any other kind of tissue. At times the growth from the explanted intestine or heart contains only cells with thread-and rod-shaped mitochondria. Again, a large proportion of such cells contain only large granules. These granules are frequently so large that they are clearly seen with the low power. They are collected about the central body and appear to be more refractive than other types of mitochondria. Occasionally these large granules fuse. That they are not a 
degenerate form of mitochondria is shown by the fact that such cells frequently divide. In case of mitosis the mitochondria spread around the nucleus, and the large granules become short rods or dumbbell-shaped rods.

While these certain characteristic appearances of the mitochondria are found as a rule in the different kinds of cells, nevertheless the shape, position, size and quantity vary so much that it is not always possible to distinguish the kind of cell by the appearance of the mitochondria.

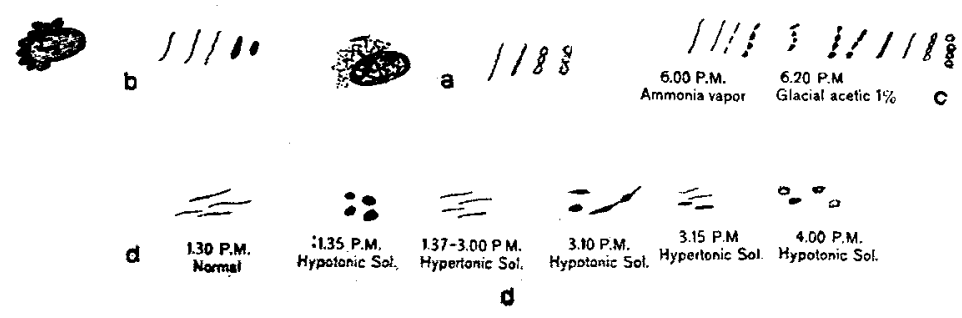

Fig. $19 A$, effect of 2 per cent glacial acetic acid vapor on the nucleus and adjoining mitochondria and upon a single thread-like mitochondria; $b$, effect of strong ammonia water vapor on another nucleus with adjoining mitochondria and on a single thread-like mitochondrium, the reaction in both cases was almost instantaneous; $c$, effect of ammonia vapor on a single mitochondrium followed after 20 minutes by the vapor of 1 per cent glacial acetic acid; $d$, effect of hypoand hypertonic solutions on 4 mitochondria.

\section{EXPERIMENTAI, WORK}

Mitochondria in the living cell react rapidly and definitely to certain stimuli and in many cases they react more rapidly than either the cell as a whole or any other structure of the cell. This reaction, to be sure, often resembles a disintegration of the mitochondria and results in the rapid formation of varicose mitochondria and then the separation of the varicose mitochondria into a number of small, finely granular rings.

\section{Reaction to acids}

When the culture is subjected to the action of carbonic acid gas (fig. $13 \mathrm{e}$ ) or the vapor of acetic, sulphuric, hydrochloric, chromic and other acids (fig. $19 \mathrm{a}, 13 \mathrm{~d}$ ) the mitochondrial threads rapidly assume a varicose condition and soon separate into a 
number of small granular rings of uniform size. Hydrogen peroxide, potassium permanganate and chlorotone, each produce a similar result.

\section{Reaction to alkalies}

Alkalies, ammonia gas and sodium hydroxide, on the other hand, cause the mitochondria to swell without any sign of varicosity. The nucleus also becomes larger and more transparent (fig. $19 \mathrm{~b}$ ).

If the ammonia vapor is followed by vapor from acetic acid the acid will cause the mitochondria and also the nucleus to return to the normal condition. We have not succeeded in stopping the action of the acid at this point, however, and the mitochondria become degenerate rings (fig. $19 \mathrm{c}$ ).

\section{Reaction to xylol, chloroform, ether}

Xylol, chloroform, and ether simply remove the mitochondrial material, or possibly dissolve the mitochondria and leave shadow forms or slight traces of degenerate mitochondria.

\section{Reaction to hyper and hypotonic solutions}

Changes in osmotic pressure affect the mitochondria often before any change is seen in the cytoplasm. Hypertonic solutions shrink the mitochondria while hypotonic solutions cause them to become swollen. The effect of a hypertonic solution can be removed by a decrease in the osmotic pressure of the solution, and, vice versa, that of a hypotonic by an increase in the osmotic pressure (fig. $19 \mathrm{~d}$ ).

\section{Reaction to heat}

Heat gives interesting results. With an increase in the temperature of the warm stage on . which the preparation is studied from 40 to $48^{\circ} \mathrm{C}$, the mitochondria become round granules within fifteen or twenty minutes, regardless of their previous shape (fig. 20). The size of these round granules is determined by 
the size of the mitochondrial thread or rod before the heat began to act. When the heat is applied the mitochondria do not divide into a number of granules, as is sometimes the case when Janus green is used, but each one rounds up as a whole and forms one round granule for each mitochondrium. With rapid cooling of

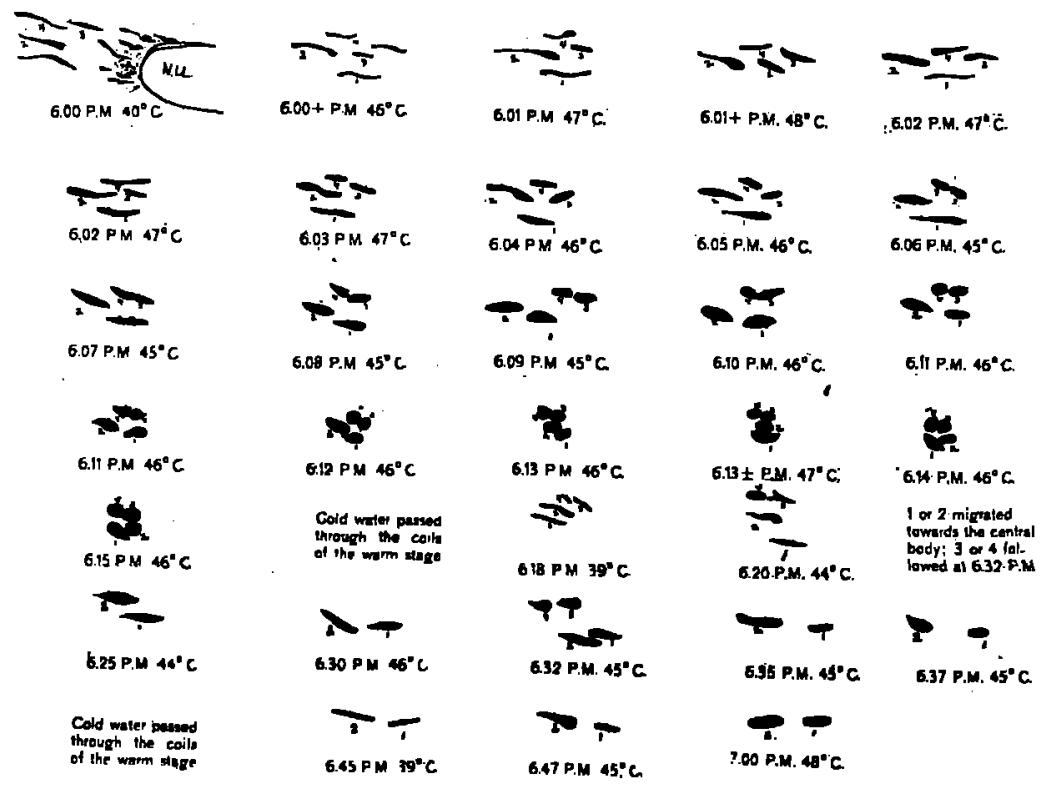

Fig. 20 Part of living cell, drawn with camera lucida, showing position of 4 mitochondria which were drawn at intervals, while the temperature was first increased and kept at 46 to $48^{\circ} \mathrm{C}$. for 15 minutes, then cooled to $39^{\circ}$ for 3 minutes and again increased to 44 to $46^{\circ}$ for 20 minutes; again cooled to $39^{\circ}$ for $8 \mathrm{~min}-$ utes, and finally increased to $48^{\circ}$ again.

the preparation, by passing cold water through the coils of the warm stage, the mitochondria return to their normal shape Prolonged heat, such as $46^{\circ} \mathrm{C}$. for over an hour, has in a few instances reduced the number and also the size of the mitochondria in a given cell. 
VITAL DYES

Janus green

Janus green (di-ethyl saffranin azo di-methyl aniline) has been considered a more or less specific stain for mitochondria in the living cell, according to Laguesse ('99), Michaelis ('99), Bensley ('11), Cowdry ('12-'14). Unfortunately, in our preparations, while the dye stained the mitochondria a brilliant blue-green, it was also toxic to the cells, and even the weakest solution $(1-200,000)$ which definitely stained the mitochondria caused the death of the cells within a few hours. Not only did the dye prevent further growth, but in most instances it also caused various amounts of distortion of the mitochondria. In a few

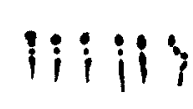

a

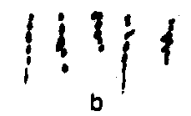

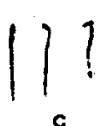

c

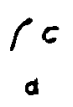

Fig. 21 Changes exhibited by 4 different cells after application of Janus green; in $a$ and $b$ the mitochondria were all long threads before the Janus green was applied and had begun to split up before the drawings could be made.

cases the mitochondria moved, changed shape and appeared quite normal, although distinctly stained, but usually the mitochondrial threads or rods separated into granules (fig. 21), shortly after the stain was applied. This is an indication of a slight degree of degeneration on the part of the mitochondria (see experimental work) and possibly the cell is already injured, although not so greatly as to interfere immediately with the activities of the cell, as in many cases the cell continued to move after the stain had been applied and in one observation on a heart muscle cell in which the mitochondria granules were deeply stained with a $(1-100,000)$ Janus green solution the cell continued to beat for one hour and forty minutes. At the end of this time the stain had faded out and the cell ceased to beat.

The dye was dissolved in the Locke's solution, which was used for that particular explantation, and after a drop of the solution containing the dye warmed to $39^{\circ} \mathrm{C}$. had been dropped 
on the growth it was drawn off and the tissue again bathed in a fresh drop of the warm solution free from dye. The mitochondria take up the dye within a few minutes and remain stained from thirty minutes to two hours. So far as we have observed, the intensity with which the mitochondria stain does not depend upon the strength of the solution. A very weak solution $(1-100,000)$ gives as intensely stained mitochondria as does a strong solution (1-5000). A weak solution, such as 1-100,000 Janus green, stains only the mitochondria a bluegreen, while the cytoplasm, nucleus, and nucleolus remain clear. A strong solution (1-5000), however, stains the cytoplasm a pale green, the mitochondria a darker green, the nucleolus green, and the nucleus a more or less violet-green.

\section{Nile blue $B$ extra and brilliant cresyl blue $2 b$}

Aside from Janus green, no dye used in these observations stained the mitochondria in the living cell. Both nile blue $A$ concentrated or B extra and brilliant cresyl blue $2 \mathrm{~B}$, however, did stain the mitochondria after the death of the cell, especially after fixation either with neutralized formalin vapor or osmic acid vapor. This is interesting in connection with the work of Lorrain Smith ('08) on differential stains for fats. He states as follows:

It was observed that watery solutions of nile blue sulphate (A), a colour stuff of the oxazine series, stains the fat globules contained in tissue cells in various colours. In the majority of cases the fat globules are stained a brilliant red; occasionally globules are present which take a blue stain, and not infrequently the colour is due to a mixture of blue and red. . . . We may express the reaction in the following way: The fatty acid combines with the oxazine base to form a blue soap, whereas both neutral fat and fatty acid merely dissolve the relatively weak oxazone base (red).

$\mathrm{He}$ remarks in relation to tissues fixed with formalin that the globules stain readily either red or blue according to their composition:

When a globule contains a small amount of fatty acid and a large amount of oxazone base is present in the solution of the dye, the globule becomes predominately red, whereas if the stain is relatively weak in oxazone the blue colour of the oxazine staining is more apparent. 
We found that not only do nile blue (A concentrated and B extra) and brilliant cresyl blue $(2 \mathrm{~b})$ show the above changes of color found by Smith ('08) with fats but also that each dye changes from blue to pink in the presence of certain other substances as shown in table 1 .

Both brilliant cresyl blue $2 \mathrm{~b}$ and nile blue $\mathrm{B}$ extra are toxic to the cell, and a preparation never lived more than an hour after even the weakest $(1-200,000)$ solution of the nile blue B extra. Brilliant cresyl blue $2 \mathrm{~b}$ is less toxic than nile blue and each of these stains is in a way antiseptic, for no infection took place after the stain was used although the dye was not sterilized. The color reactions with these stains on the living and on the dead cells are shown in table 2.

TABIF 1

\begin{tabular}{|c|c|c|c|}
\hline & & $\begin{array}{l}\text { NILE BLUE } \\
\text { B EXTRA }\end{array}$ & $\begin{array}{c}\text { BRILLIANT CRESYL } \\
\text { BLUE 2B } \\
\end{array}$ \\
\hline 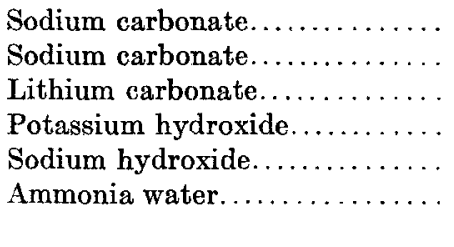 & $\begin{array}{c}\text { (in solution) } \\
\text { (dry) } \\
\text { (in solution) }\end{array}$ & $\begin{array}{l}\text { blue } \\
\text { red } \\
\text { pink } \\
\text { pink } \\
\text { pink } \\
\text { precipitate red }\end{array}$ & $\begin{array}{l}\text { blue } \\
\text { bluish violet } \\
\text { violet } \\
\text { pink } \\
\text { pink } \\
\text { dirty brown } \\
\text { solution }\end{array}$ \\
\hline
\end{tabular}

TABLE 2

\begin{tabular}{|c|c|c|c|c|c|c|c|}
\hline & CYTOPLASM & NUCLEUS & NUCLEOLOS & $\begin{array}{c}\text { FAT } \\
\text { DHOPLETS }\end{array}$ & $\begin{array}{c}\text { VAC DOLES } \\
\text { (FIG. 22) }\end{array}$ & $\begin{array}{c}\text { OTHER } \\
\text { GRANULES }\end{array}$ & $\begin{array}{l}\text { MITOCHON- } \\
\text { DRIA }\end{array}$ \\
\hline \multicolumn{8}{|c|}{ Living cell } \\
\hline $\begin{array}{l}\text { Nile blue } \\
\text { B extra } \\
\text { Brilliant } \\
\text { cresyl blue } \\
2 \mathrm{~b}\end{array}$ & $\begin{array}{l}\text { clear } \\
\text { clear }\end{array}$ & $\begin{array}{l}\text { clear } \\
\text { clear }\end{array}$ & $\begin{array}{l}\text { clear } \\
\text { pale } \\
\text { blue }\end{array}$ & $\begin{array}{c}\text { refrac- } \\
\text { tive } \\
\text { refrac- } \\
\text { tive }\end{array}$ & $\begin{array}{l}\text { pink } \\
\text { pink }\end{array}$ & $\begin{array}{l}\text { blue } \\
\text { purple }\end{array}$ & $\begin{array}{l}\text { clear } \\
\text { clear }\end{array}$ \\
\hline \multicolumn{8}{|c|}{ Dead or fixed cell } \\
\hline $\begin{array}{l}\text { Nile blue } \\
\text { B extra }\end{array}$ & $\begin{array}{l}\text { pale } \\
\text { blue }\end{array}$ & blue & $\begin{array}{l}\text { blue- } \\
\text { violet }\end{array}$ & blue & clear & blue & blue \\
\hline $\begin{array}{l}\text { Brilliant } \\
\text { cresyl blue } \\
2 \mathrm{~b}\end{array}$ & $\begin{array}{l}\text { pale } \\
\text { violet }\end{array}$ & $\begin{array}{l}\text { blue- } \\
\text { violef }\end{array}$ & blue & blue & clear & purple & $\begin{array}{l}\text { gray- } \\
\text { violet }\end{array}$ \\
\hline
\end{tabular}


The difference in the results obtained when these dyes are used upon dead cells and when used upon living cells shows clearly that the chemical conditions which exist in the living cell are quite different from those in the dead cell. What happens in the living cell to prevent the mitochondria and fat globules from taking on the pink or blue color which is assumed immediately upon the death of the cell? Was the dye itself oxidized and why did the vacuoles and certain other granules stain? The vacuole certainly does not take the pink color due to the presence of fat of any kind, for death of the cell would hardly remove the fat but would only change it possibly from neutral to acid fat and the vacuole should then change from pink to blue color instead of fading out entirely. If on the other hand the pink color is due to the alkaline nature of the vacuoles, why then does it not either remain pink or else become blue? Why does the nucleus remain unstained until death of the cell begins and then the nucleolus first take on the stain and later the nucleus? Is the pale blue color of the nucleus after brilliant cresyl blue $2 \mathrm{~b}$ in the living cell a delicate indicator that the cell is injured by the dye? These are but a few of the questions suggested by the different action of these dyes upon the dead and the living cell and which must be left for the physiological chemist to solve.

This change is most readily seen when a cell has first been stained while it is living and then fixed under the microscope. As the preparation dies the pink vacuoles fade out and the nucleolus, the nucleus, cytoplasm, fat globules and mitochondria stain. This is not due to the direct action of the fixative upon the stain itself since a fixed preparation which has been well washed with Locke's solution gives the same results with these dyes.

\section{Iodine}

It might be mentioned in this connection that while the vapor from a crystal of iodine did fix the mitochondria as reddish brown threads, rods and granules, there was no evidence of any port wine colored granules of glycogen attached to any 
mitochondrium nor within the loop or ring shaped mitochondria. A few glycogen granules were occasionally present, however, as could be distinguished by the color reaction. The fat globules stain first a pale port wine color which later becomes blackened. If Guilliermond's ('13) conclusion that the loop-shaped mitochondria give off glycogen granules is correct, one would certainly expect to find that iodine used in connection with unfixed material would show this at least during the final stage in the formation of the glycogen when the granule lies free but still in the neighborhood of the mitochondrium from which it came.

CERTAIN OTHER CELL STRUCTURES AND THEIR RELATION TO THE MITOCHONDRIA

\section{Granules}

Certain other granules were present in most of the cells of these growths, but so far, these granules have not been carefully studied. They can be differentiated from mitochondria of similar shape by the greater rapidity with which the granules move through the cytoplasm. Certain of the vital dyes which color these granules leave the mitochondria unstained. Neutral red usually stains one or several granules near the central body. Nile blue B extra and brilliant cresyl blue $2 \mathrm{~b}$ also stain certain granutes near the central body. In cells which contain the body we have termed vacuole (see below) one or more of these granules are present within the vacuoles and are stained blue within a pink vacuole (nile blue $B$ extra) or purple within a pink vacuole (brilliant cresyl blue $2 \mathrm{~b}$ ). These granules are few in number in the normal cell but plentiful in cells which contain many vacuoles. Other vital dyes stain certain granules within the cell, but so far as our observations go they are the same as the neutral red granules or else as the nile blue, and brilliant cresyl blue granules.

At times the granules within the vacuole take the Janus green color as a very pale green, but no other relation between these granules and the mitochondria has been found. 


\section{Vacuoles}

There are two distinct types of degeneration of the cells of the tissue cultures. The cell either suspends activities, rounds up and dies, or else the cell continues its usual activities but the cytoplasm becomes filled up with vacuoles and the mitochondria become small granules (fig. 22). In a healthy cell a vacuole is often seen to come and go in the cytoplasm, but when several vacuoles remain in the cytoplasm degeneration has begun and the cell never again resumes its normal appearance, but continues to accumulate vacuoles until most of the cytoplasm is used up and only a network which contains scattered granules remains.

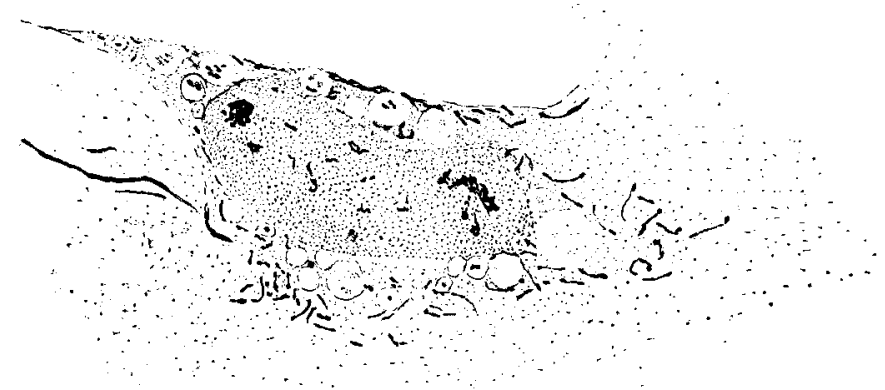

Fig. 22 Cell from a 3-day culture of intestine from a 7-day chick embryo; the cell has a number of vacuoles near the nucleus, most of the vacuoles contain one or more granules; $\times 1580$ diam.

In the fixed and stained preparations the vacuole appears either as a clear space often difficult to differentiate from the fat globule space, or it appears as a clear space within which is a faintly stained granular substance (gray with Heidenhain's iron hematoxylin or red brown with Bensely's anilin fuchsin, methylen green stain).

In the living cell these vacuoles are distinctly different from the fat droplets. They appear to be fluid spaces not at all refractive, in fact, they resemble a hole in the cytoplasm. Small dancing granules which vary in number from one to many may be suspended in the fluid of the vacuole or closely attached to 
the side. These granules usually stain a pale green with Janus green stain.

Nile blue $B$ extra and brilliant cresyl blue $2 \mathrm{~b}$ each act as a differential stain for these bodies. The vacuole stains pink and the granules blue (nile blue B extra) or purple (brilliant cresyl blue $2 \mathrm{~b}$, fig. 23 ).
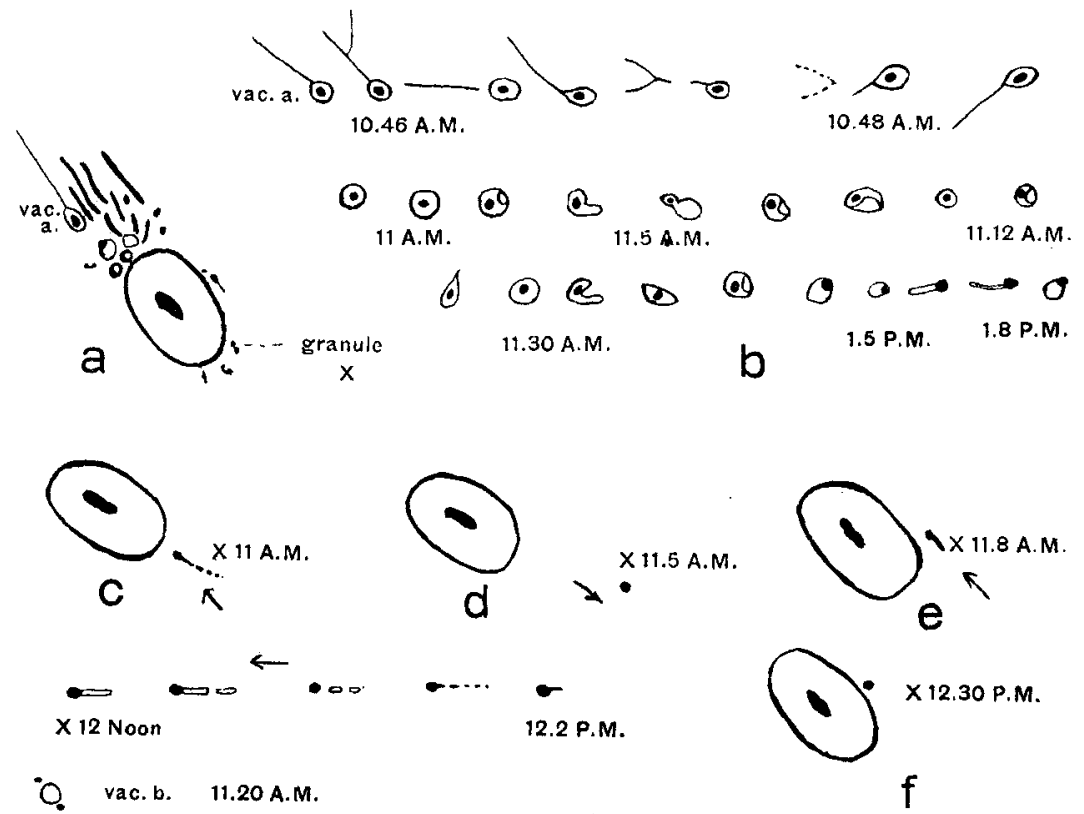

O. vac.b. 11.20 A.M.

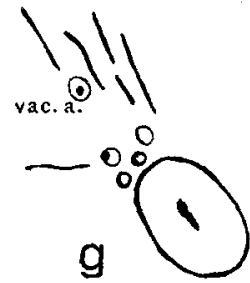

vac. b. $\mathrm{O}$

11.20 A.M.

$\odot \underset{12 \text { Noon }}{\Theta}$<smiles>C=C[13C](=C)[13CH]=CI</smiles>

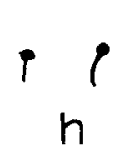

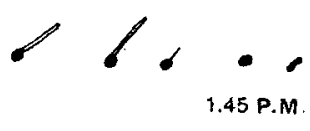

$\begin{array}{lll}\text { i vac.c. } & \text { O } & \mathrm{O} \\ 12.15 \text { P.M. }\end{array}$
8

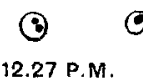

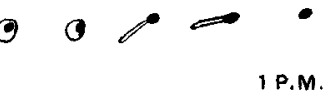

Fig. 23 Observations on the behavior of vacuoles in the living cell with brilliant cresyl blue $2 \mathrm{~B}$ (see text). 
Brilliant cresyl blue $2 \mathrm{~b}$, which is much less toxic than nile blue $B$ extra, shows a most interesting behavior on the part of these vacuoles and granules. A vacuole may appear in the cytoplasm as a clear unstained space which at first contains no granules, but within five to ten minutes the granules appear as dancing bodies as though they were the result of some condensation and precipitation within the vacuole. This process continues and the vacuole takes on first a pale violet color, but later a bright pink, and the granules condense into one or two purple granules. Then the vacuole exhibits various movements such as sending out long pink streamers or threads or becoming U-shaped. Such a vacuole may decrease in size until only the purple granule can be seen. When a cell which contains many vacuoles is stained, all gradations between the pale non-granular vacuole to the single purple granule can be seen.

One of the many observations made upon healthy cells in which vacuoles appear is given in full below (fig. 23).

10.45 A.M. 1 gtt. $(1-100,000)$ brilliant cresyl blue 2b in Locke's solution +0.25 per cent dextrose was placed on the preparation.

10.50 A.M. The cytoplasm remains clear, several purple granules appear. The mitochondria are unstained, slightly refractive bodies, the fat globules are unstained and highly refractive, the nucleus is unstained, but the nucleolus is a pale blue (fig. $23 \mathrm{a}$ ). There is present one vacuole in the cell, which is stained a brilliant pink and contains a large purple granule. The vacuole sends off a long pink streamer quite as long as the thread-like mitochondria but not so thick (fig. 23 , vac. a.). The vacuole manifests great activity. The streamer at times becomes detached from the vacuole and fades out. Again it appears to be drawn into the vacuole or sent out from the vacuole. Fig. $23 \mathrm{~b}$.

11.00 A.M. The streamer no longer appears, and the vacuole itself begins to change shape (fig. $23 \mathrm{~b}$ ) and continued until 11.30 when the vacuole began to grow smaller and a deeper pink. It then remained more or lèss quiet but grew much smaller in size.

1.05 P.M. The vacuole again sent off a pink streamer which lasted only two or three minutes, after which the small vacuole with one large granule remained quiet.

11.00 A.M. A small granule ( $x$ ) at the other side of the nucleus moves rapidly to and fro between the nucleus and the periphery several times (fig. $23 \mathrm{c}, \mathrm{d}, \mathrm{e}, \mathrm{f}$ ). A streamer of pink follows the purple granule until at 12 noon while the granule moved rapidly towards the nucleus the streamer broke off two pink granules which instantly faded out. 
12.30 A.M. The granule shows no sign of pink vacuo'e or streamer and remains quiet near the nucleus.

11.20 A.M. A clear unstained vacuole (vac.b.) appeared in the cytoplasm between two of the purple granules (fig. $23 \mathrm{~g}$ ) and behaved as follows, (fig. $23 \mathrm{~h}$ ).

11.30 A.M. It became a pale violet vacuole with a few dancing unstained granules.

11.45 A.M. It was a violet vacuole with purple granules.

11.50 A.M. Violet vacuole became pink with purple granules.

12.00 Noon. The vacuole condensed into a small bright pink vacuole with only one purple granule.

12.13 P.M. The vacuole entirely disappeared and only the purple granule remained.

12.20 P.M. Purple granule sent out a pink streamer.

12.45 P.M. The pink streamer osculates and is rapidly sent out and drawn in again.

1.45 P.M. The granule became quiet and the streamer disappeared. The purple granules later moved as a rod from the periphery of the cell in towards the nucleus and back several times. It passed over and under the mitochondria without hindrance. Other purple granules in the cell moved rapidly without streamers, some as double granules, others as rods or as single round gramules.

12.10 P.M. A pale space appeared in an adjoining cell (fig. $23 \mathrm{i}$ ).

12.15 P.M. This space became pale violet.

12.20 P.M. Violet color changed to pink.

12.25 P.м. Granules appeared in the vacuole.

12.27 P.м. Granules became deep purple granules.

The mitochondria and the fat globules remain unstained in all the cells of the growth. In some other cells of the growth many pink vacuoles are present and also many purple granules. In such cells the mitochondria are mostly small granules and only a few rod- or threadlike ones remain. In the cell under observation the mitochondria did not change type although they were continually changing shape.

There was no direct connection between the mitochondria and the formation of the vacuoles in the above observation, and yet in many cells there is often a coincident change in the shape of the mitochondria until in cells which contain many vacuoles within the cytoplasm the mitochondria are no longer in the shape of rods and threads but then appear as small granules.

As stated above, the fixed and stained preparations (fig. 24 a) do seem to show all stages in the formation of the vacuoles from the mitochondria just as Dubreuil and Guilliermond have shown the formation of bodies from the mitochondria. However, the fact that the vacuoles have been observed to arise 
independently of the mitochondria, although there is a coincident change in the shape of the mitochondria makes one exceedingly wary of accepting any evidence from the fixed and stained preparations in this regard without corroboration from observations upon the living cell.
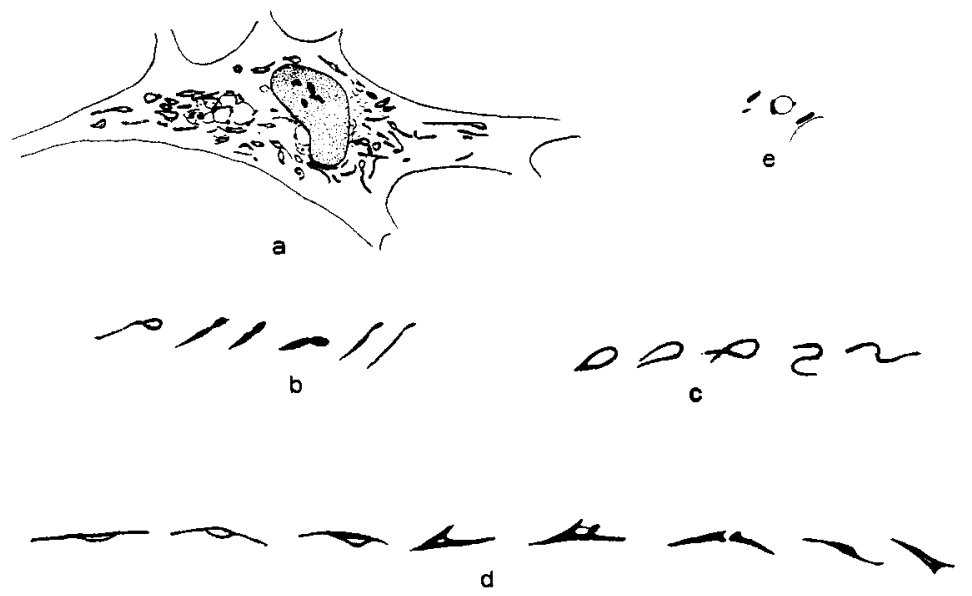

Fig. 24 One-day culture of heart from a 5-day chick embryo; $a$, cell with various shaped mitochondria similar to those figured by Dubreuil and Guilliermond, which led them to conclude that mitochondria formed fat and other bodies. Observations on this cell while living gave no evidence for the formation of such bodies from the mitochondria; $b$ and $c$ show successive forms of two mitochondria from the above cell and $d$ also shows changes exhibited by a single mitochondrium that Guilliermond might have interpreted as showing the formation of a droplet; $e$, the rod-shaped mitochondrium which is applied closely to the vacuole was observed, while the cell was living, to migrate from some little distance to the vacuole; it had no connection with the formation of the vacuole. If the specimen had been fixed to show the condition, as in $e$, one might have concluded that the mitochondrium had something to do with the formation of the vacuole or droplet.

Certainly the mitochondria are intimately connected with any change in the cytoplasm, often as in the case of heat without manifestation of change by other bodies in the cytoplasm, and it is probable that any change which takes place in the cytoplasm such as would cause the formation of vacuoles or other bodies would also have an influence upon the mitochondria of that cell. 


\section{Fat globules}

The connection between the mitochondria and the formation of fat is a very complex and much discussed subject. It has undoubtedly been shown that the mitochondria are bodies which contain lipoid (Fauré-Fremiet '09; Regaud and Mawas '09; Fauré-Fremiet, Mayer, Schaeffer, '10; Regaud '10; Mawas '10; Mayer, Rathery, Schaeffer, '10; Duesberg '11; Dubreuil '13; Cowdry '14). Our experimental work shows that the mitochondria act in many ways like bodies which contain lipoid. They are soluble in xylol, chloroform or ether, are slightly blackened by means of osmic acid, and in fixed preparations are stained blue by means of nile blue B extra and yellow by means of Sudan III. It seems probable that the bodies which contain lipoid should form the fat globules, and many observers have tried to establish this (Metzner '90, Zoja '91, Loyez '09, Russo '09, Dubreuil '13). Others have claimed that the mitochondria are indirectly connected with the formation of fat (Bluntschli '04, Van der Stricht '05, Van Durme '07, Lams and Doorme '08, Schoonjams '09).

The masterly papers of Dubreuil ('11, '13) appear to show clearly and concisely each step in the formation of fat droplets from the mitochondria, and without doubt from the fixed material which Dubreuil had at hand it seemed to be the logical conclusion that the fat is formed from the mitochondria. Guilliermond ('13) in a set of observations equally clear uses many figures similar to those of Dubreuil, but reaches the conclusion that the mitochondria form the glycogen granules of certain cells. It is certainly evident from our observations that no definite conclusions can be drawn from the morphology of the mitochondria present in any one cell at any one time. Various chemical tests and continued observation of a given mitochondrium are necessary to establish any morphological conclusion.

In our fixed preparations (fig. 24 a) all the figures shown by Dubreuil as evidence that the mitochondria form the fat can be found, i.e., threads, loops, rings and fat droplets, but the study of any one such mitochondrium in the living cell has 
never shown that fat droplets arise from mitochondria (fig. $24 \mathrm{~b}, \mathrm{c}, \mathrm{d})$. A thread may form a loop, but the loop changes back again into a thread instead of continuing into a ring. Various rings studied have never changed into globules during observation but have become rods or threads or granules. Such appearances as figure $24 \mathrm{e}$, were caused by the migration of a mitochondrium to the edge of a vacuole and not as both Dubreuil and Guilliermond might conclude, that the mitochondrium formed the vacuole. Certain granules or thick rods seen in the living cell have the appearance of hollow bodies in the permanent preparations and correspond to some of Dubreuil's figures. This appearance may be due to fixation as Kingsbury ('11) suggests, i.e., that the osmic acid reduced more at the surface and later the more soluble interior is dissolved out. Both Meves ('08) and Duesberg ('11) describe the clear inner part of the mitochondrium, to quote Duesberg, the mitochondria were first present in the early rabbit embryo as small granules but these increase in volume and become large granules at the end of the third day. They have a clear central part with a dark outer edge. Such appearance was seldom seen in the living cell and it is possible that these as well as certain figures of Dubreuil and Guilliermond were formed by the method of fixation. Cells which contain both loop and ring shaped mitochondria frequently show no sign of fat formation, while other cells which are accumulating fat show no mitochondria of the shape which Dubreuil leads us to suppose form the fat droplets.

There are three distinct types of fat in these tissue culture growths. First, that in the cells which grow out from tissues that at the time of explantation of the piece of tissue, contained fat droplets as the yolk membrane or the migrating fat cells. There seems to be a predetermined ability on the part of these cells to form fat, as is clearly shown where the growth from the yolk membrane adjoins that from the connective tissue (fig. 25). Each new yolk membrane cell contains fat droplets similar to those of the explanted piece of the yolk membrane. In these cells the mitochondria are usually in the form of small granules and the fat droplet is surrounded by granules which 
stain like mitochondria. In the migrating fat cells which contain few fat globules some of the mitochondria may be in the form of threads or short rods but there is a coincident change in the shape of the mitochondria with the accumulation of fat droplets so that a cell which is crowded full of fat droplets contains

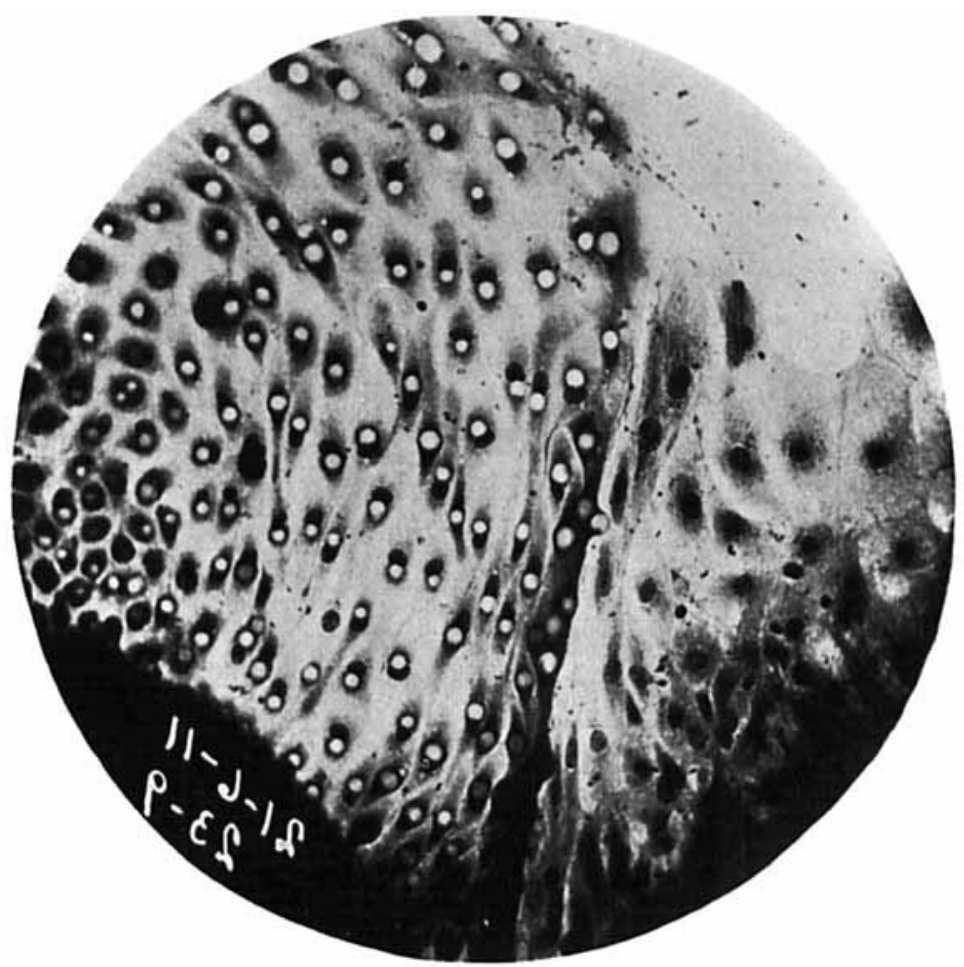

Fig. 25 Photograph of part of a 2-day culture of intestine from a 6-day chick. The explanted piece of intestine is from the region where the yolk-sac is attached, and the cells on the left of the culture are similar to those from cultures of the yolk-sac; each endodermal cell has one or two large fat globules; on the right are mesenchyme cells free or almost free from fat.

only small granule shaped mitochondria. The fat droplets are outlined by a row of granules which stain like mitochondria (fig. 26 b).

The second type of fat is one or two small round refractive granules found in almost all the cells of the growths. These fat globules have not been observed to increase markedly in 
size or to change their shape. During mitosis they remain stationary and all may pass over to one daughter cell or part to one and part to the other daughter cell. No relation between these fat globules and the mitochondria was observed. Cells which contain one or no fat globules often contain loop or ring shaped mitochondria, but prolonged observation of these has not shown any inerease in the amount of fat. The third type of fat is that of an accumulation of fat droplets in many of the
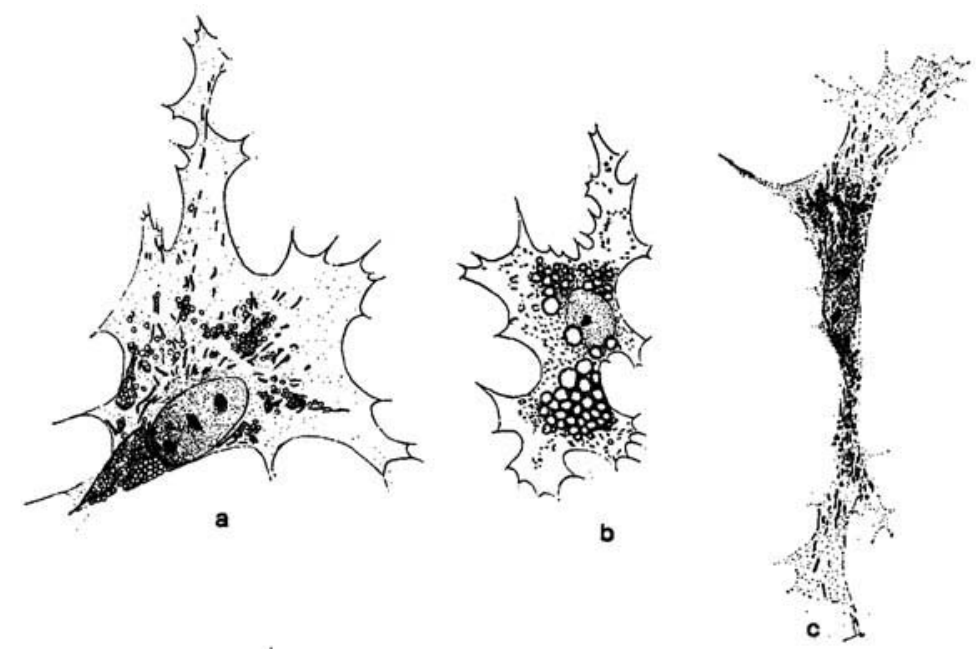

Fig. $26 A, b$, cells from a 2-day culture of heart from a 10-day chick in which fat is accumulating; $a$ was studied while living, after staining with nile blue $B$ extra, after osmic acid vapor, after nile blue B extra again, Sudan III and Bensley's aniline fuchsin methylene green. No relation could be found between mitochondria and the formation of fat; $b$, a typical wandering fat cell with many small granular mitochondria about the fat droplets; $c$, cell from a 2 -day culture of heart from a 11-day chick, accumulating fat; prolonged fixation with osmic acid followed by iron hematoxylin; the fat appears as dark granules.

cells of a preparation due to some unknown cause (fig. 26 a, c). These cells accumulate fat droplets from day to day, and some cells may become crowded full of fat droplets within forty-eight hours. Such cells should show the relation between the mitochondria and the fat globules were such a relation present, but so far as our observations go none such could be established.

These three types of droplets are undoubtedly fat. It is possible to treat the same cell with various fat stains in succes- 
sion and to compare the results. The cell shown in figure 26 a was first studied and drawn while living. The clear, refractive fat globules were easily recognized. A drop of nile blue B extra $(1-100,000)$ was added without any change in the appearance of either the fat globules or of the mitochondria. After a few minutes this was washed off and the preparation was fixed in osmic acid vapor for a few minutes. The same cell was then examined and the fat globules were stained a yellow brown, while the mitochondria remained clear. A drop of nile blue $B$ extra was then added. The fat globules took a dark blue stain and the mitochondria a pale blue. A drop of Sudan III was then added and the fat became yellow while the mitochondria stained a trace of blue. The specimen was then dehydrated and stained with Bensley's anilin fuchsin, methylene green. The fat droplets were dissolved and the mitochondria stained a brilliant red.

Early in the experimental work it was observed that the mitochondria under certain conditions became granules around a vesicle. This vesicle stained pink with the nile blue B extra in the living cell, and at that time it was supposed that this indicated the formation of a fat by the mitochondria since Lorrain Smith ('08) had shown that nile blue stained neutral fat pink in tissue cells. Later it was observed that nile blue B extra only stains fat in the dead and not in the living cell, and therefore there was no indication that the mitochondria are in any way connected with the formation of fat.

So far as our observations go they show no direct relation between the mitochondria and the formation of fat, although in some cases there is a coincident change in shape of the mitochondria with the accumulation of fat droplets.

\section{Canalicular system}

One of the interesting cytoplasmic structures, the canalicular system, found by other observers, has as yet not been observed in these living cells.

Bensley ('11) by means of neutral red observed the small canaliculi as clear spaces in the deeply stained pancreatic cell. 
In the cells of tissue cultures neutral red stains only a few granules unless used in such strong solutions as to stain the entire cytoplasm. In such cases a few clear unstained spaces were seen, but a study of the living cell and of the same cell fixed after the neutral red stain by means of osmic vapor and stained with Bensley's anilin fuchsin, methylen green stain demonstrated that the clear space seen in the cells stained with strong neutral red solution are only the unstained mitochondria.

The description of the Binnennetz given by Perroncito ('11) certainly resembles in many ways the behavior of the mitochondria in the tissue culture cells. He finds a network which is like that sometimes seen in these cells, and the 'corona' of granules shown in some of his figures appears very much like the mitochondria granules radiating out around the central body. In some of our permanent preparations where vacuoles are present these spaces have all the appearance of the canalicular system.

Prolonged fixation in osmic acid did not reveal the canalicular system, although the mitochondria became slightly blackened by the action of the osmic acid. However, none of the special stains for the canalicular system were used, as we desire to deal only with the structures seen in the living cell.

\section{Amitosis and giant cells}

Many cells of these growths contain two or more nuclei and the membrane within the nucleus, which Childs ('07) described as connected with amitosis, is occasionally seen in such cells, but no definite relation between such cells and the mitochondria has been observed. Certainly in some giant cells containing many nuclei, the number of mitochondria present is far greater than that present in a normal cell of the same growth, in fact, it is so much greater that it seems to be definitely related to the amount of nuclear material and to the extent of the cytoplasm. These cells show clearly that there is some other method of increase in the number of mitochondria than that of division at the time of mitosis, for these giant cells appear to be formed 
by an amitotic division of the nucleus without a coincident division of the cytoplasm.

In regard to the structures of the differentiated cell, such as muscle fibrillae, etc., we have no observations to offer. However, from the behavior of the mitochondria in various shaped cells it is quite evident that any change which affected the morphology of the cell might also change the position of the mitochondria in such a way that they might appear to be connected with the formation of the differentiating structure.

\section{DISCUSSION}

We have made no attempt to formulate a theory from the above observations in regard to the origin or function of the mitochondria. A review of the literature shows that the mitochondria have been found in almost every kind of cell. They are present in the oocyte and spermatocyte (Benda '97, Van der Stricht '00, Meves '11, and others) and are carried over by the spermatozoon into the egg cell in fertilization (Benda '11, Meves '11); they are abundant in cells of the young embryo (Meves '08, Rubaschkin '11); they occur in plant cells as well as in the cells of most animals, including certain of the Protozoa (Lams '09, Duesberg '10, Meves '04, Guilliermond '12). It is claimed that they form certain cytoplasmic structures such as the fibrillae of the connective tissue (Meves '10), the neurofibrillae in the growing neuroblast (Hoven '10), the myofibrillae (Duesberg '10, Torraca '14) the fibrillae of the epithelial cell (Herxheimer '89, Korotneff '09, Fauré-Fremiet '10, Firket '11); that they play a part in the process of cornification (Firket '11); that they form the secretory granules, directly or indirectly, in the salivary (Regaud and Mawas '09, Bouin '05), gastric (Schultze '11), mammary (Hoven '11) and other glands (Schultze '11). They are described in the rods of the urinary tubule cells (Schultze '11, Regaud '08), in the intestinal cells (Champy '10), in the liver cell (Policard '09). They may form the test of the foraminifera (Fauré-Fremiet '13). They are described in connection with the formation of the retina cells (Leboucq '09). 
Numerous observers have claimed that they form the fat directly (Altmann '89-'95, Metzner '90, Zoja '91, Arnold '07, Russo '07, Loyez '09, Van der Stricht '05, Policard '09, Frissinger '09, Regaud '10, Fauré-Fremiet '10, Dubreuil '13); indirectly (Bluntschli '04, Van der Stricht '05, Van Durme '07, Lams and Doorme '08, Schoonjans '08). It is claimed that they form the leucoplastids, chloroplastids and chromoplastids and possibly the glycogen (Guilliermond '12-'13).

The above theories seem impossible to correlate. It seems evident that the mitochondria are too universal in all kinds of cells to have the function of forming any one of the above structures of differentiated tissue, and in the light of what cytological chemistry is known, it appears practically impossible for the mitochondria to form all the cell structures mentioned above. In view of the fact that the mitochondria are found not only in almost all animal cells but in plant cells as well it seems more probable that they play a rôle in the more general physiology of the cell. It may be possible that they are concerned with respiration. As suggested by Kingsbury ('12), they may represent the structural expression of the reducing substances concerned in cellular respiration, which process Matthews ('05) has described in his theory of protoplasmic respiration. According to Matthews, the activity of the cell causes reducing bodies to be formed in the cytoplasm for whose neutralization oxygen is necessary. The lipoid nature of the mitochondria makes it possible to consider them as reducing bodies and certainly the mitochondria exhibit activities which may be due to the fact that they are continually formed in the cytoplasm and continually oxidized. On the other hand, the mitochondria may have to do with assimilation or they may even be stored-up food-stuff themselves, which are continually used up and restored again. Beckwith ('14) holds that the mitochondria are unnecessary for the life of the cell or for the development of such a complicated structure as a Hydractinia ciliated planula. The fact that such a large group of observers should each have evidence to show that the mitochondria form some one structure of the differentiated cell shows that the mitochondria must be 
intimately connected with all transformations of the cytoplasm. On the other hand, we must bear in mind the fact that many observers have neglected to identify the body which they had under observation in such a manner that one can be certain that they had the same body which another observer would term mitochondria. It is quite doubtful whether all the bodies called mitochondria are really the same.

The criterion for mitochondria in the embryonic cell, as stated by Duesberg after Montgomery, is one which the observer would hesitate to carry out, but some criterion in the sex cell, in the embryonic cells and also in the adult cells should be established for the mitochondria, which all workers will endeavor to fulfil, in order that there may be some common ground for discussion of the results obtained by the numerous observers at work in this field.

\section{CONCLUSION}

1. Tissue cultures afford an excellent method for observations upon an undisturbed cell as it lives, divides and grows in a medium of known chemical constitution; for experimental work on a living cell; and for the study of the process of fixation.

2. These living cells do not correspond to the usual conception of a cell obtained from the study of fixed material. Both cytoplasm and nucleus are finely granular, almost homogenous in appearance. There is no sign of a reticular or of an alveolar structure of either the cytoplasm or nucleus. Osmic acid vapor is the best fixative for these cells.

3. Mitochondria are present in all the cells of these growths as slightly refractive, large or small granules, rods and threads, similar to those of the chick embryo cell. The mitochondria can be followed and 'studied in the living unstained cell for hours.

4. The mitochondria may be scattered throughout the cytoplasm or they may be located around the nucleus or around the idiozome. Any one mitochondrium may change its position in regard to other mitochondria or in regard to the entire cell. Mitochondria located around the centra some may later migrate 
out and become scattered through the cytoplasm, or those scattered throughout the cytoplasm may become located around the nucleus. During mitosis the mitochondria become more evenly scattered throughout the cytoplasm, except in the spindle area, where they are usually absent.

5. Any and every shape granule from a minute to a large granule, from small short rods to long threads, loops, rings and networks of various shapes and sizes can be found. Any one type of mitochondria such as a granule, rod or thread may at times change into any other type or may fuse with another mitochondrium, or it may divide into one or several mitochondria. Every type of mitochondria is continually changing shape and may assume as many as fifteen or twenty shapes in ten minutes. The shape of all the mitochondria in a cell can be changed by experimental means such as heat or hyper- or hypotonic solutions.

6. The mitochondria vary greatly in size from minute granules to irregularly shaped, large granules, from short rods to long threads. The size of a single mitochondrium may change by the fusion of two or more granules or by the division of a single mitochondrium. They also appear to increase or decrease without such fusion or division.

7. The number of mitochondria in a single cell varies from two or three to over two hundred. The number of mitochondria is not constant for any one kind of cell or for any phase of any one kind of cell. Daughter cells contain about one-half the number of mitochondria present in the mother cell. The number of mitochondria increases from the daughter cell to the mature dividing cell, and apparently also at times during mitosis.

8. The quantity of mitochondria is not constant for any one kind of cell. Some cells with many small granular mitochondria contain less mitochondrial substance than other cells with a few large granules.

9. Degenerating mitochondria become first a series of granules; later the granules become vesicles and then separate into a number of small finely granular rings which stain like the cytoplasm rather than like mitochondria. 
10. The mitochondria become more or less scattered throughout the cytoplasm in an indifferent manner and decrease in size during mitosis. About one-half the quantity of mitochondria is separated into each daughter cell by the plane of division. The individual mitochondria pass over entire into one or the other daughter cell and do not each divide into two halves, each going to one daughter cell, as usually described.

11. There are some characteristic differences in the mitochondria of different kinds of cells, but these are not constant enough to be sufficient to distinguish the kinds of cells.

12. The mitochondria are extremely plastic bodies and often react more rapidly than any other cell structure. They are easily influenced in shape and quantity by varous agents, such as heat, carbon dioxide, acids, alkalies, fat solvents, and potassium permanganate, or by changes in osmotic pressure of the surrounding medium.

13. The mitochondria are stained in these living cells by Janus green but not by nile blue B extra or brilliant cresyl blue $2 \mathrm{~b}$ except in the dead cell.

14. Other granules are present in the cells which are not related to mitochondria.

15. Mitochondria show at times a coincident change in shape with the formation of fat droplets or vacuoles in the cytoplasm, but there is no evidence in these cells of a direct relation between the mitochondria and the formation of either the fat droplets or the vacuoles.

16. In giant cells the number and quantity of mitochondrial substances is greatly increased above that of the normal cells, somewhat in proportion to the increase in the amount of the cytoplasm and nuclear material.

The mitochondria are extremely variable bodies, which are continually moving and changing shape in the cytoplasm. There are no definite types of mitochondria, as any one type may change into another. They appear to arise in the cytoplasm and to be used up by cellular activity. They are, in all probability, bodies connected with the metabolic activity of the cell. 


\section{BIBLIOGRAPHY}

Altmann, R. 1894 Die Elementarorganismen und ihre Beziehungen zu den Zellen. Leipzig.

ARnold, J. 1898 Uber Struktur und Architektur der Zellen. I, II, III. Arch. f. mikr. Anat., Bd. 52.

BARRETT, J. O. Wakelin 1913 Changes in the chondriosomes occurring in pathological conditions. Quart. Jour. Micr. Sci., vol. 58.

Becston, H. 1910 On granules in cells of normal tissues and new growths. Arch. Middlesex Hosp., vol. 19.

BeCKwITH, C. J. 1914 The genesis of the plasma-structures in the egg of $\mathrm{Hy}$ dractinia echinata. Jour. Morph., vol. 25, no. 2.

IJENDA, D. 1899 Weitere Beobachlungen über die Mitochondria und ihr Ver. haltnis zu Secretguanulationen, nebst kritischen Bemerkungen. Verh. d. Phys. Ges., Berlin.

1903 Die Mitochondria. Ergeb. d.Anat. u. Entw., Bd. 12.

BensLey, R. R. 1910 On the nature of the canalicular apparatus of animal cells. Biol. Bull., vol. 19, no. 3, p. 192.

1911 Studies on the pancreas of the guinea-pig. Am. Jour. Anat., vol. 12.

Blunrschli, H. 1904 Beobachtungen am Ovarialei der Monascidie Cynthia. microcosmus. Morph. Jahrb., Bd. 32.

Bouis, P. 1905 Ergastoplasme et mitochondria dans les cellules glandulaires séreuses. Compt. rend. Soc. Biol., vol. 62.

Browne, E. 1913 Study of the male germ cells in Notonecta. Jour. Exp. Zoöl., vol. 14, no. 1.

von Brunv, A. 1884 Samenkörper und ihrer Entwickelung bei Säugetiern und Vögeln. Arch. f. mikr. Anat., Bd. 23.

Buchner, P. 1909-1911 Referate in Arch. f. Zellf., Bd. 2, 5, 6.

Cega, Bianchi P. 1910 Contributo alla conoscenza della anatomie e della fisio patologia renale. Internat. Monatschr. f. Anat. u. Phys., Bd. 27.

Cerrog, C. M. 1907 Amitosis as a factor in normal and regulatory growth. Anat. Anz., Bd. 30.

Craccio, C. 1911 Sui mitochondri degli elementi linfoidi e mieloidi. Pathologica, vol. 3.

Cowdrx, E. V. 1912 The relations of mitochondria and other cytoplasmic constituents in spinal ganglion cells of the pigeon. Internat. Monatschr. f. Anat. u. Phys., Bd. 30.

Dobretir, G. 1911 a Les mitochondries des cellules adipeuses. Compt. rend. Soc. Biol.

1911 b Transformation directe des mitochondries et des chondriocontes en graisse dans les cellules adipeuses.

1913 Le chondriome, etc. Arch. d.Anat. Micr., T. 15.

Duesbera, J. 1909 a ther Chondrisomen und ihre Verwendung zu Myofibrillen beim Huhnerembryo. Verh. d. anat. Ges in Giessen.

$1909 \mathrm{~b}$ Sur la continuité des éléments mitochondriaux des cellules sexuelles et des chondriosomes des cellules embryonnaires. Anat. Anz., Bd. 35, p. 548. 
Dutesberg, J. 1910 Les chondriosomes des cellules embryonnaires du Poulet et leur rôle dans la génèse des myofibrilles. Arch. f. Zellf., Bd. 4, pp. 602-67. Taf. 28-30, 10 text figs.

1911 Plastosomen, apparato reticolare interno und chromidial apparat. Erg. d. Anat. u. Entwick.

Duesberg, J. 1910 Les chondriosomes des cellules embryonnaires du Poulet et leur rôle dans la génèse des myofibrilles. Arch. f. Zellforschung., Bd. 4.

Eisen, G. 1900 The spermatogenesis of Batrachseps. Jour. Morph., vol. 17.

Fatre-Frìmiet, E. 1909 Sur les réaction de quelques mitochondries. Compt. rend. Acad. des Sciences de Paris.

1910 Étude sur les mitochondries des Protozoaries et des cellules sexuelles. Arch. d'Anat. micr., T. 11.

Faure-Frìmet, M. E., Mayer, A., and Schaeffer, G. 1910 Sur la microchimie des corps gras: Application a l'étude des mitochondries. Arch. d'Anat. micr., T. 12.

Finkar, J. 1911 Recherches sur la génèse des fibrilles ćpidermiques chez le Poulet. Anat. Anz., Bd. 38.

Gurumfarmond, A. 1911 a Sur les mitochondries des cellules végétales. Compt. rend. Acad. des Sci., Paris.

1911 b Sur la formation des chloroleucytes aux dépens des mitochondries. Compt. rend. Acad. des Sci., Paris.

1913 Sur les mitochondries des champignons. Soc. de Biol.

Heidnnhain 1911 Plasma und Zelle 2 Lief.

Herxiermer, K, 1889 Uber eigentümliche Fasern in der Epidermis und Epithel verschiedener Schleimhäute. Arch. f. Dermat. u. Syph., Bd. 21.

Hoven, H. 1911 Du rôle du chondriome dans l'elaboration des produits de sécrétion de la glande mammaire. Anat. Anz., Bd. 39.

Koldarewsky 1887 Inaug. Diso Ber.

KingSBdRY, B. F. 1911 Chromaffin system and the nature of the chromaffin reaction. Anat. Rec., vol. 5. 1912 Cytoplasmic fixation. Anat. Rec., vol. 6.

Kopsch, Fr. 1902 Die Darstellung des Binnennetzes in spinalen Ganglien zellen und anderen Körperzellen mittelst Osmiumsaüre. Sitzungaber d. k. preuss. Akad. d. Wiss. zu., Berlin.

Konotner, A. 1909 Mitochondrien. Chondriomiten und Faserepithel der Tricladen. Arch. mikr. Anat., Bd. 74.

1910 Histologische Beobachtungen über die Mitochondrien sowie die Struktur und Entwickelung der Muskelfasern einiger Wirbellosen. Arch. f. Zellf., Bd. 5.

Laguesse, E. 1899 Origine du zymogène. Compt. rend. Soc. Biol.

LAms, H. 1909 Demonstration de mitochondries dans les cellules végétales. Verh. anat. Ges., Berlin.

Lams, H., AND Doorme, J. 1908 Nouvelles recherches sur la maturation et la fécondation de l'oeuf des Mammifères. Arch. de Biol., T. 23.

Leвоucc, G. 1909 a Contribution à l'ćtude de l'histogenèse de la rétine chez les Mammifères. Arch. d'Anat. micr., T. 10.

1909 b Êtude sur la limitante externe de la rétine. Ann. Soc. Méd. de Gand., T. 89. 
Lewis, W. H., and Lewis, M.R. 1911 The growth of embryonic chick tissue in artificial media, agar and bouillon. Johns Hopkins Hos. Bull., vol. 22, no. 241, April.

1912 a The cultivation of sympathetic nerves from the intestine of chick embryos in saline solutions. Anat. Rec., vol. 6, no. 1, January. $1912 \mathrm{~b}$ The cultivation of chick tissues in media of known chemical constitution. Anat. Rec., vol. 6, no. 5, May.

1912 c Membrane formations from tissues transplanted in artificial media. Anat. Rec., vol. 6, no. 5, May.

1914 Mitochondria in tissue culture. Sci., N. S., vol. 39, no. 1000, February 27.

Loyez, M. 1909 Les premiers stades de la vitellogénèse chez quelques Tuniciers. Compt. rend. Assoc. Anat., Nancy.

1911 Sur la structure de l'oocyte de la femme à la période d'accroissment. Compt. rend. Assoc. Anat., Paris.

Mann, G. 1902 Physiological histology: Method and theory. Oxford, Clarendon Press.

Mathews, A. P. 1905 A theory on the nature of protoplasmic respiration and growth. Biol. Bull., vol. 8.

Mawas, J. 1910 Etude cytologique et physiologique sur la rétine ciliaire des Mammifères. Arch. d'Anat. micr., T. 12.

Mayer and RAthery 1909 Recherches sur l'histophysiologie de la sécrétion urinaire chez les Mammifères. Arch. d'Anat. micr., T. 11.

Mayer, Rathery and Schaeffer 1910 Sur les propriétés des granulations ou mitochondries de la cellule hépatique normale. Compt. rend. Soc. Biol.

Metzner, R. 1890 U̇ber die Beziehungen der Granula zum Fettansatz. Arch. f. Anat. u. Entwick.

Meves, F. 1908 Die Chondriosomen als Träger erblicher Anlagen Cytologische Studien am Hühnerembryo. Arch. f. mikr. Anat., Bd. 72.

1909 Demonstration von Chrondriokonten in Bindegewebszellen, Knorpelzellen, Osteoblasten und Knochenzellen des Hühnerembryo. Verh. anat. Ges. Giessen.

1910 a Zur Einigung zwischen Faden und Granulalehre des Protoplasma. Beobachtungen an weissen Blutzellen. Arch. f. mikr. Anat., Bd. 75.

1910 b Ueber Strukturen in den Zellen des embryonalen Stützgewebes, sowie über die Entstehung der Bindegewebsfibrillen, insbesondere derjenigen der Sehne. Arch. f. mikr. Anat., Bd. 75, pp. 148-224.

1911 Über die Beteiligung der Plastochondrien an der Befuchtung des Eies von Ascaris megalocephala. Arch. f. mikr. Anat., Bd. 76. 1913 Über das Verhalten des plastomatischen Bertandteiles des Spermiums bei der Befruchtung des Eies von Phalluria Manillota. Arch. f. mikr. Anat., Bd. 82, abt. 2, p. 215.

Michaelis, L. 1899 Die vitale Färbung, eine Darstellungsmethode der Zell. granula. Arch. f. mikr. Anat., Bd. 55.

Michaelis, M., and WolfF, A. 1902 Uber Granula in Lymphozyten, Virchow's, Arch., Bd. 167. 
Mistavsky, A. N. 1911 a Demonstration von chondriosomen in Pankreaszellen. Verh. Anat. Ges., Leipzig.

1911 b Beitrage zur Morphologie der Drüsenzelle. Über das Chondriom der Pankreaszelle einiger nager. Vorl. Mitteil. Anat. Anz., Bd. 39.

Montgomery, T. H. 1911 The spermatogenesis of an Hemipteron, Euschistus. Jour. Morph., vol. 22, no. 3.

Perroncito, A. 1911 Beiträge zur Biologie der Zelle. Arch. f. mikr. Anat., Bd. 77.

Policard, A. 1909 Sur la structure des mitochondries. Compt. rend. Soc. Biol. 1910 Contribution à l'étude du mécanisme de la sécrétion urinaire. Arch. d'Anat. micr., T. 12.

Polichrd, A. et Garnier, M. 1905 Altérations eadavériques des épithéliums rénaux. Compt. rend. Soc. Biol.

1907 Des lésions rénales provoqués par l'injection de Phlorhizyne. Compt. rend. Soc. Biol.

Rawitz, B. 1907 Lehrbuch der mikroscopischen Technik. Leipzig.

Regaud, Cr. 1909 Participation du chondriome a la formation de grains de ségrégation, etc. Compt. rend. Soc. Biol., T. 66.

1910 Etude sur la structure des tubes séminifères et sur la spermatogénèse chez les Mammifères. Arch. d'Anat. micr., T. 11.

Regaud, ex Mawas, J. 1909 Sur la structure du protoplasmé, etc. Compt. rend. Assoc. Anat., Nancy.

Retzius, G. 1910 Utber den Bau des Eies derEchinodermen im unbefruchteten und befruchteten Zustand. Biol. Unters. Neue Folge, Bd. 15.

Rubaschkin, W. 1910 Chondriosomen und Differenzierungsprozesse bei Säugetierembryonen. Anat. Hefte, Bd. 41.

Russo, A. 1909 I. mitocondri ed i globuli vitellini nell'oocite di coniglia allo stato normale ed in condizione sperimentali. Atti Accad. Gioenia. Catania, Ser. 5, vol. 2.

1910 Sui mutamenti che subiscono i mitocondrî ed i materiali deutoplasmici dell'oocite di coniglia in diversi periodi di inanizione. Arch. f. Zellf, Bd. 4-5.

Sarae, Saguchi 1913 Über Mitochondria in die Epidermiszellen der Anurenlarven. Arch. f. mikr., Anat., Bd. 83, Part III.

Samssonow, N. 1910 Über die Beziehungen der Filarmasse Flemmings zu den Fäden und Körnern Altmanns etc. Arch. f. mikr. Airat., Bd. 75.

SchaXeL, J. 1911 Plasma strukturen, Chondriosomen und Chromidien. Anat. Anz., Bd. 39.

Schoonjans, H. 1909 Étude sur la phase d'accroissement des ovocytes chez Ascaris megalocephala bivalens. Bull. Soc. Roy. Sci. Med., Brussels.

Schultze, O. 1911 Ủber die Genese der Granula in den Drüseuzellen. Anat. Anz., Bd. 38.

SJövall, E. 1906 Über Spinalganglionzellen usw. Anat. Hefte, vol. 30.

Sмiтн, T. L. 1906 Method for staining fat by means of basic dyes. Jour. Path. and Bact., vol. 11.

1908 On the simultaneous staining of neutral fats and fatty acids by oxazine dyes. Jour. Path. and Bact., vol. 12. 
Takaki, К. 1907 t'ber die Stäbchenstruktur der Niere. Arch. f. mikr. Anat., Bd. 70.

TORRACA, L. 1914 Il comportamento dei condriosomi nella regenerazione dei muscoli striati. Arch. f. Zellf., Bd. 12.

VAN Der Stricht, O. 1905 La structure de l'oeuf des Mammifères. II Partie. Bull. de l'Acad. Roy. de Belgique.

1905 La structure de l'oeuf de chauvc-souris. (V. noctula). Compt. rend. Assoc. Anat., Geneve.

VAN Durme, M. 1907 Les mitochondries et la méthode de Sjövall dans l'oogénèse des oiseaux. Ann. de la Soc. de Med. de Gand., T. 87.

Vejdovskr, F. 1907 Neue Untersuchungen über die Reifung und Befruchtung. Kön Böhm Ges. der. Wiss., Prag.

Veratri, E. 1909 Sulla fina struttura delle cellule di alcuni timori. Boll. Soc. Med. Chir., Pavia.

Wilson, E. B. 1911 The cell. Pp. 163.

ZoJA, I, F. R. 1891 Intorno ai plastiduli fucsinofili (bioblasti dell' Altmann). Mem. del. R. Ist. Lomb. di sci., vol. 16. 